\title{
Plant allelochemicals: agronomic, nutritional and ecological relevance in the soil system
}

\author{
Aurelio Scavo • Cristina Abbate • Giovanni Mauromicale $\mathbb{D}$
}

Received: 11 September 2018 / Accepted: 21 June 2019 /Published online: 4 July 2019

(C) Springer Nature Switzerland AG 2019

\begin{abstract}
Background Allelopathy is an ecological phenomenon consisting of both positive and negative effects between organisms determined by the release of secondary metabolites into the environment. Root exudation represents the most important pathway of releasing allelochemicals. Once released into the soil, allelochemicals interact with the organic and inorganic soil phases, as well as with soil microorganisms. The set of these interactions fix allelochemicals bioavailability and phytotoxic level.

Scope Here we critically review the interactions between plant allelochemicals and physical, chemical and biological soil characteristics by reporting the literature available and pointing out both positive and negative relationships affecting allelochemicals phytotoxicity and nutrient availability. In addition, we have reported a qualitative balance of allelochemicals in the soil. Thirdly, we
\end{abstract}

Responsible Editor: Ismail Cakmak.

A. Scavo $\cdot$ C. Abbate $\cdot$ G. Mauromicale $(\bowtie)$

Department of Agriculture, Food and Environment (Di3A), University of Catania, via Valdisavoia, 5, 95123 Catania, Italy

e-mail: g.mauromicale@unict.it

\section{A. Scavo}

e-mail: aurelio.scavo@unict.it

C. Abbate

e-mail: cristina.abbate@unict.it

G. Mauromicale

Trees and Timber Institute, National Research Council (CNR-IVALSA), via P. Gaifami, 18, 95126 Catania, Italy reviewed the exudation process of allelochemicals and the transport mechanisms across plasma membranes.

Conclusions A two-way relationship exists between soil characteristics and allelochemicals. The level of phytotoxicity is not affected only by a single soil characteristic, but they are closely linked to each other and exert a multiple-effect on retention, transport and transformation processes of allelochemicals in soil. Further efforts are needed to better understand the interactions involved in soil allelopathy and to create new opportunities for a sustainable control of agroecosystems.

Keywords Allelopathy - Secondary metabolites .

Rhizosphere · Root exudation · Soil characteristics · Soil microorganisms

\section{Introduction}

In recent years, agriculture has had to deal with increasing environmental pollution mainly arising from two aspects linked by a common goal: the maximization of yields. On one hand, the improper utilization of synthetic chemicals for weed and pest control in agroecosystems; on the other, the mismanagement of fertilization, principally for nitrogen. Allelopathy has offered a new alternative for the development of ecofriendly agricultural practices, with the dual purpose of enhancing crop productivity and maintaining ecosystem stability (Scavo et al. 2018a). Allelopathy involves the positive or negative effects of a plant (donor), including microorganisms, on neighbouring plants (targets) 
through the release of chemical compounds into the environment, mostly in the soil. According to Inderjit and Weiner (2001), it is possible to distinguish between direct plant-plant allelopathic interference (allelopathy in the narrow sense) and indirect allelopathy. The former refers to the direct action of an allelochemical produced and released by a donor plant on receiver plants; the latter represents the effects of allelochemicals on abiotic and biotic soil processes that affect other plants. Aldrich (1984) described these two kinds of allelopathy as true and functional allelopathy. Indeed, allelochemicals released into the soil can (i) directly affect the target organisms, (ii) be degraded or transformed by soil microorganisms, (iii) induce a third species to produce another compound which interferes with donor plants and (iv) cause changes to soil abiotic factors that affect target plants. Most have focused on the in vitro direct allelopathy and the identification of potential allelochemicals. However, it is impossible to separate direct from indirect allelopathic effects in field conditions and to assert that direct allelopathy is solely responsible for an observed phenomenon in the field, because many abiotic and biotic soil factors influence the fate of allelochemicals. Therefore, indirect allelopathic interactions, from an ecological point of view, are probably more important in plant communities than direct ones (Inderjit and Weiner 2001). For this reason, we believe that they should be further investigated by the scientific community under a soil chemical ecology context.

How allelochemicals must reach the root system of the target plant through the soil in order to exert a phytotoxic effect, has been well documented (Inderjit 2001). However, establishing an allelopathic interference depends on several factors such as the concentration, the movement and the persistence of allelopathic compounds. In fact, allelochemicals are subjected to transformations by the complex of chemical, physical and biological characteristics of the soil environment that determine their phytotoxic level (Blum 2006; Cheng 1992; Dao 1987). Soil characteristics, especially biological ones, may vice versa be affected by allelochemicals. Thus, there is a two-way relationship between them. However, these relationships have been little investigated by the scientific community. Finding a linkage may help researches in studying and increasing the knowledge on the allelopathic behaviour of plants. Allelochemicals released into the rhizosphere exert a significant impact on nutrient availability, dynamics and uptake by the plant. A broader knowledge of the effects of plant allelochemicals on mineral nutrient soil cycles, heavy metal detoxification and nutrient solubility can enhance the nutrient use efficiency through a reduction of their losses and the development of a more efficient and sustainable fertilization technique.

This review focuses on the interactions between plant allelochemicals and physical, chemical and biological soil characteristics from an agronomic and ecological point of view, by reporting the literature available on this topic and pointing out both the positive and negative relationships affecting allelochemicals phytotoxicity. Moreover, a qualitative balance of allelochemicals inputs and outputs in soil was developed. Furthermore, we also discuss the exudation process of allelochemicals and the transport mechanisms across plasma membranes. The influence of plant allelochemicals on mineral nutrition and the most important plant-soilmicroorganism interactions are also discussed.

\section{Balance of allelochemicals in soil}

Donor plants release allelochemicals into the environment through volatilization from living parts of the plant, leaching from plant foliage, decomposition of plant material and root exudation (Scavo et al. 2018a). Except for volatilization, the other pathways release allelopathic compounds into the soil. Once released by the donor plant, allelochemicals enter into a complex plant-soil system in which different factors affect their availability and, consequently, their effective influence on target plants (Blum et al. 1999; Kruse et al. 2000). This plant-soil system, is in turn influenced by several meteorological factors, demonstrating the complexity of this phenomenon. As shown in Fig. 1, in addition to the chemical nature of the allelochemical produced, the phytotoxic activity of allelochemicals in the soil is affected by climatic conditions (e.g. solar radiation, temperature, rainfall), soil factors (e.g. texture, $\mathrm{pH}$, ionexchange capacity, organic matter content, nutrient dynamics, moisture content and microbial ecology) and plant factors of both the donor and target plants (e.g. species, botanical variety, growth stages, plant parts, etc.). Since the pathways of release of allelochemicals into the environment, as well as plant and meteorological factors affecting their production, have already been reviewed in depth (de Albuquerque et al. 2011; Rice 1984; Scavo et al. 2018a), this article addresses root 
exudation, which is the most important pathway of release of such secondary metabolites into the soil, and soil factors (physical, chemical and biological) interacting with allelochemicals.

In order to be adsorbed by the roots of the target plant, allelochemicals may be present in the soil solution (Kobayashi 2004). Therefore, the key factor determining the phytotoxic activity of allelochemicals is their concentration in soil water. However, similar to herbicides, in the soil environment these compounds are subjected to retention, transformation and transport processes (Cheng 1992; Weidenhamer 1996). Retention is a physical process consisting in the interaction (frequently described as adsorption or sorption) between allelochemicals and soil particles (e.g. clays, Fe-, Al-, and Mn-sesquioxides, organic matter), water and/or air (Bezuidenhout and Laing 2006; Cheng and Koskinen 2010). In many cases, it is a dynamic and reversible process implying the mobility of allelochemicals in soil. Transformation is a positive or negative biochemical process, mainly operated by soil microorganisms, involving the conversion of allelochemicals into more active, less active or entirely inactive compounds. This process leads to a reduction of the amount of the original allelochemical available for transport (Cheng 1992). Transport represents the movement of allelochemicals in the soil, and it is closely affected by the retention and transformation processes. The interaction of these processes is governed by the chemical nature of the allelopathic compound, the organisms involved, the properties of the soil and the environmental conditions.

Understanding the available concentration of allelochemicals in the soil solution is of central importance. As commonly found in weed science for herbicides, we have developed a conceptual framework (Fig. 2) representing a qualitative balance of allelochemicals inputs and outputs in soil, in which is possible to observe their dynamicity. In addition to the direct release by plants, allelochemicals can enter into the soil through faunal and microbial exudation (from both living microorganisms and decomposed microbial biomass), decomposition of organic matter and mineral weathering. Similar to herbicides, allelochemicals are continually removed and/or immobilised from the soil solution by leaching, microbial breakdown, adsorption to soil particles and plant uptake (Cheng 1995; Inderjit et al. 2001; Weidenhamer 1996). However, the behaviour of allelochemicals in the soil is more complicated than herbicides, as the former are continuously released from the donor plant with significant differences in relation to plant organs (Abu-Romman 2016; Iqbal et al. 2002; Suksungworn et al. 2016) and growth stages (Aslam et al. 2016). The knowledge of allelochemicals dynamicity in the soil is an important aspect for the better understanding of their interactions with plants, microorganisms and insects and for the possible future application of allelochemical-based bioherbicides, living and dead mulches.

\section{Root exudation}

Root systems have a multitude of functions including the anchorage of the plant and the absorption of water and nutrients. In addition to these main functions, roots are a site of photoassimilates storage and carbon reserves, synthesis of phytohormones (e.g. auxins, cytokinins, abscisic acid, gibberellic acid, ethylene), synthetic activities (e.g. nitrogen fixation, synthesis of organic acids, etc.), and exudation of metabolites (Blum 2006; Osmont et al. 2007). It has been estimated that over 10.000 allelochemicals are produced by higher plants, with a significant variability in their activity and mode of action in target plants (Weston et al. 2012). Living roots of many weed and crop species continuously produce and secrete both low- and high-molecular weight compounds into the rhizosphere in response to biotic and abiotic stresses (Bertin et al. 2003). The chemicals secreted into the soil by roots are broadly referred to as root exudates (Walker et al. 2003). Their quantity and quality are related to the plant species, cultivar, plant development stage, and environmental stress factors (Badri and Vivanco 2009; Uren 2000). These variables are widely reported in literature for several allelopathic plants. Aulakh et al. (2001), for example, found that rice exudation rates, in general, are the lowest at the seedling stage, increase until flowering and then decrease at maturity. Sorghum and wheat root exudations decrease with plant age and increase when the soil is stressed by compaction, drought, and low nutrient supply (Weil and Brady 2017). Generally, actively growing root systems secrete more exudates, indicating a positive correlation between root exudation and root growth (Lucas Garcia et al. 2001). In addition, the nature of root surface morphology (e.g. suberized or unsuberized, with or without mycorrhizal hyphae, thickness of periderm, quantity and location of root hairs, etc.) as well as the root system architecture 


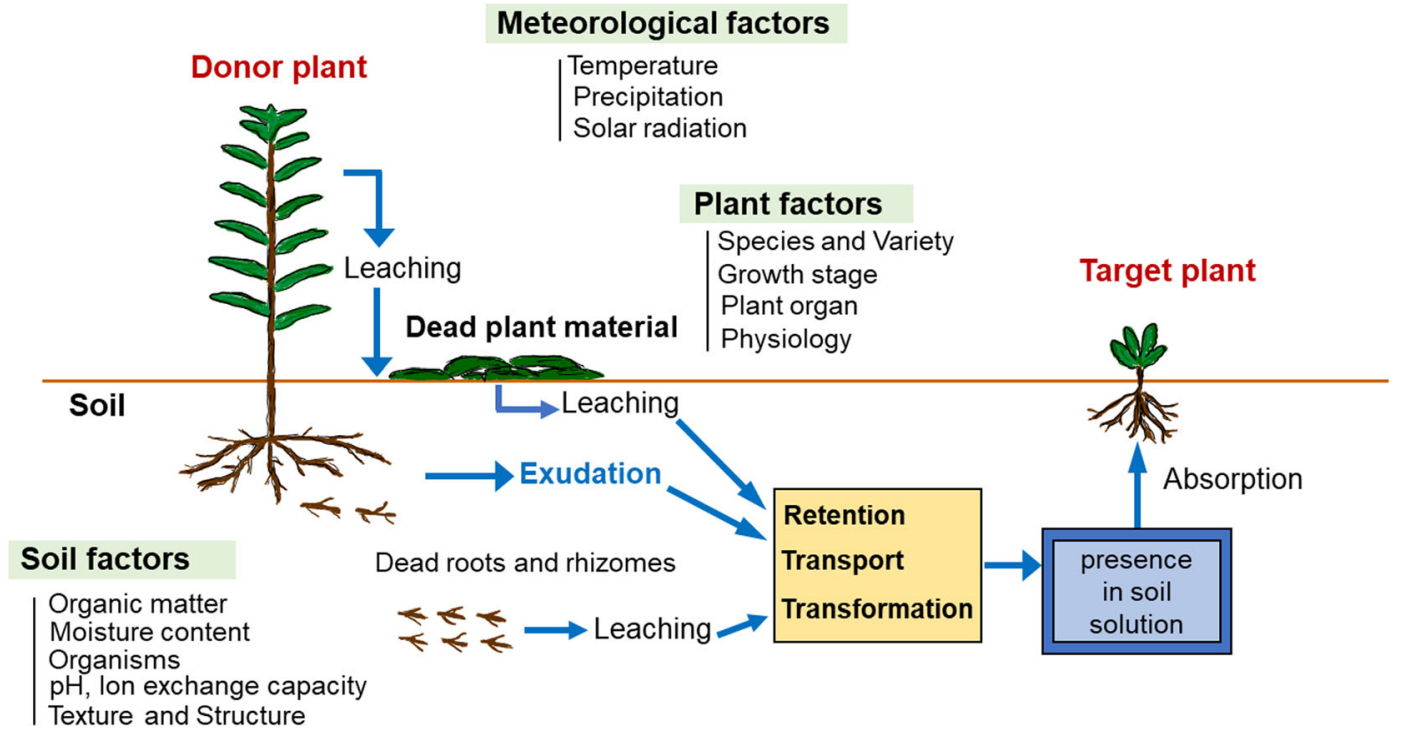

Fig. 1 Influence of meteorological, soil and plant factors on the phytotoxicity of allelochemicals in soil (modified from Kobayashi 2004). Different kinds of both meteorological and plant factors affect the quantity and quality of allelochemicals released by the

(tap root system of dicotyledonous species or fibrous one of monocotyledonous plants, amount of root branching, number of lateral roots, etc.) are all factors involved in determinating the quantitative and qualitative composition of exudates (Badri and Vivanco 2009; Blum 2006). Nevertheless, root exudation also depends on the root zone. The zone immediately behind the root tip is considered the major site of exudation (Pearson and Parkinson 1961). The root cap (CurlangoRivera et al. 2013; Hawes et al. 2012; Pina et al. 2016) and root hair cells (Czarnota et al. 2003a) are the root cells chiefly involved in root exudation, followed by cortex and stellar cells (Pineros et al. 2002). All these factors are closely correlated with each donor plant. Once released into the soil system, several soil factors influence the retention, transport and transformation processes of allelochemicals in the soil and, thus, their presence in the soil solution in order to be absorbed by the target plant

other, because the type of roots depends on plant age, season and soil conditions (e.g. texture, structure, temperature, water content, $\mathrm{pH}$, etc.).

The rhizosphere and the importance of root exudates

The narrow region of soil matrix immediately surrounding the root and in which living roots secrete an enormous range of compounds is called "rhizosphere". This term was coined by Lorentz Hiltner (Hartmann et al. 2008) to describe the portion of soil where microorganism-mediated processes are controlled by the root system (Berg and Smalla 2009). Since then, many definitions of rhizosphere have been suggested

\section{INPUTS}

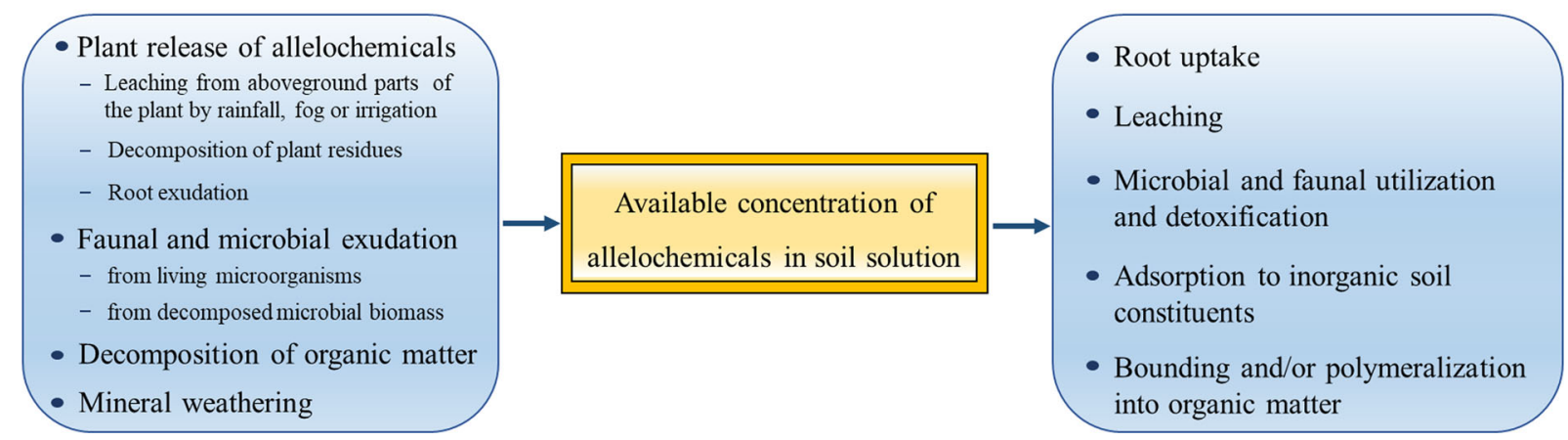

Fig. 2 Balance of allelochemicals inputs and outputs in soil affecting their bioavailability in the soil solution and phytotoxic activity 
(Kennedy 1998; McNear Jr 2013; Rovira and Davey 1974; Uren 2000). The rhizosphere can ranges from about 0 to $2 \mathrm{~mm}$ or more (depending on the plant type, soil moisture and texture, and presence of mycorrhizae) away from the root surface and includes three zones (Lynch 1987) (Fig. 3): endorhizosphere, rhizoplane and ectorhizosphere. The endorhizosphere refers to the internal zone and includes the apoplastic space between the root cortex and endodermis and is colonisable by microorganisms. Since the rhizosphere is defined as external to the root, Kloepper et al. (1992) and York et al. (2016) consider the term endorhizosphere improper. The rhizoplane, first defined by Clark (1949), represents the root surface, including epidermis and mucilage, closely adhering to the ectorhizosphere. It is the most active site of microorganism-plant interactions and plays a key role on the fate of allelochemicals in soil. The ectorhizosphere is the soil layer surrounding the root. The rhizosphere is a biologically active zone, influenced by root metabolic activities, densely populated by microorganisms. For these reasons, its chemical, biological and physical characteristics drastically differ from bulk soil. In particular, it has higher levels of cation exchange capacity, exchangeable base cations, base saturation, organic matter and carbon dioxide than bulk soil

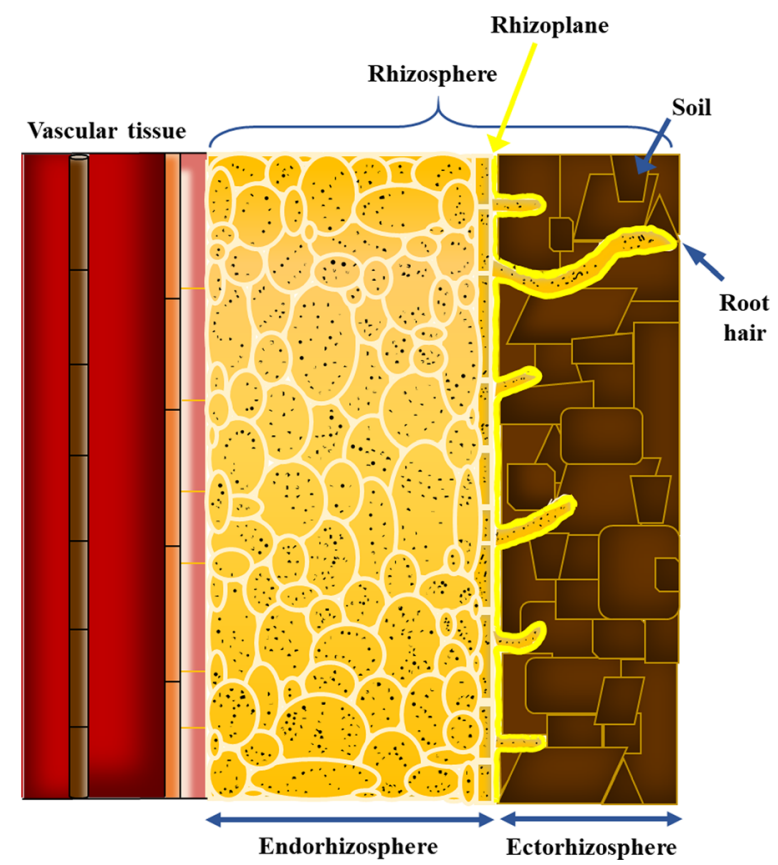

Fig. 3 Scheme of the rhizosphere showing its three sections: the endorhizosphere, the rhizoplane and the ectorhizosphere (modified from McNear Jr 2013)
(Gobran et al. 1998). The rhizosphere is characterized by gradients of its properties that change in both time and space.

The ubiquitous phenomenon consisting in the loss of carbon-containing compounds from plant roots into the rhizosphere is referred to as rhizodeposition (Doornbos et al. 2012; Jones et al. 2004). Root-derived compounds, generally called rhizodeposits, have been classified according to their mode of excretion and chemical composition into five predominate categories (Rovira 1969):

1) root exudates: sugars, amino acids, organic acids, vitamins and hormones;

2) secretions: polymeric carbohydrates, enzymes and secondary metabolites secreted with the involvement of energy;

3) mucigel: newly removed cells of cellulose, pectin, starch, and lignin, secreted by the root cap as result of abrasive forces of the root movement through the soil;

4) lysates: shedding, wall and contents of sloughed-off cells as well as whole roots;

5) gases: carbon dioxide, ethylene, etc.

Root exudation is therefore part of the rhizodeposition process. In addition to carbon-containing compounds derived from products of photosynthesis, plant roots release non-carbon-containing compounds such as the ion $\mathrm{H}^{+}$, inorganic ions, water and electrons, albeit in lower quantities (Uren 2000). However, the most dramatic changes on the physical, biological and chemical nature of the soil is produced by the release of organic carbon (Jones et al. 2009). On average, 30 to $60 \%$ of photosynthesized $\mathrm{C}$ is allocated by plants to the roots (Marschner 1995). It is estimated that about $60 \%$ of photosynthesized $\mathrm{C}$ is transferred by annual plants to the roots, while up to $70 \%$ is allocated by woody plants. According to Marschner (1995), nearly 5 to $21 \%$ of all photosynthetically fixed carbon is released into the rhizosphere through root exudates by higher plants.

Root exudation involves two different active processes: excretion and secretion (Bais et al. 2004a). The former consists in the release of metabolic wastes and mixtures of small compounds with unknown functions, while the latter refers to molecules with known functions. Root secretions are probably involved in external processes (e.g. nutrient acquisition) and have a direct ecological role in the rhizosphere. Most allelochemicals released via exudation are secretions. Excretions, on the 


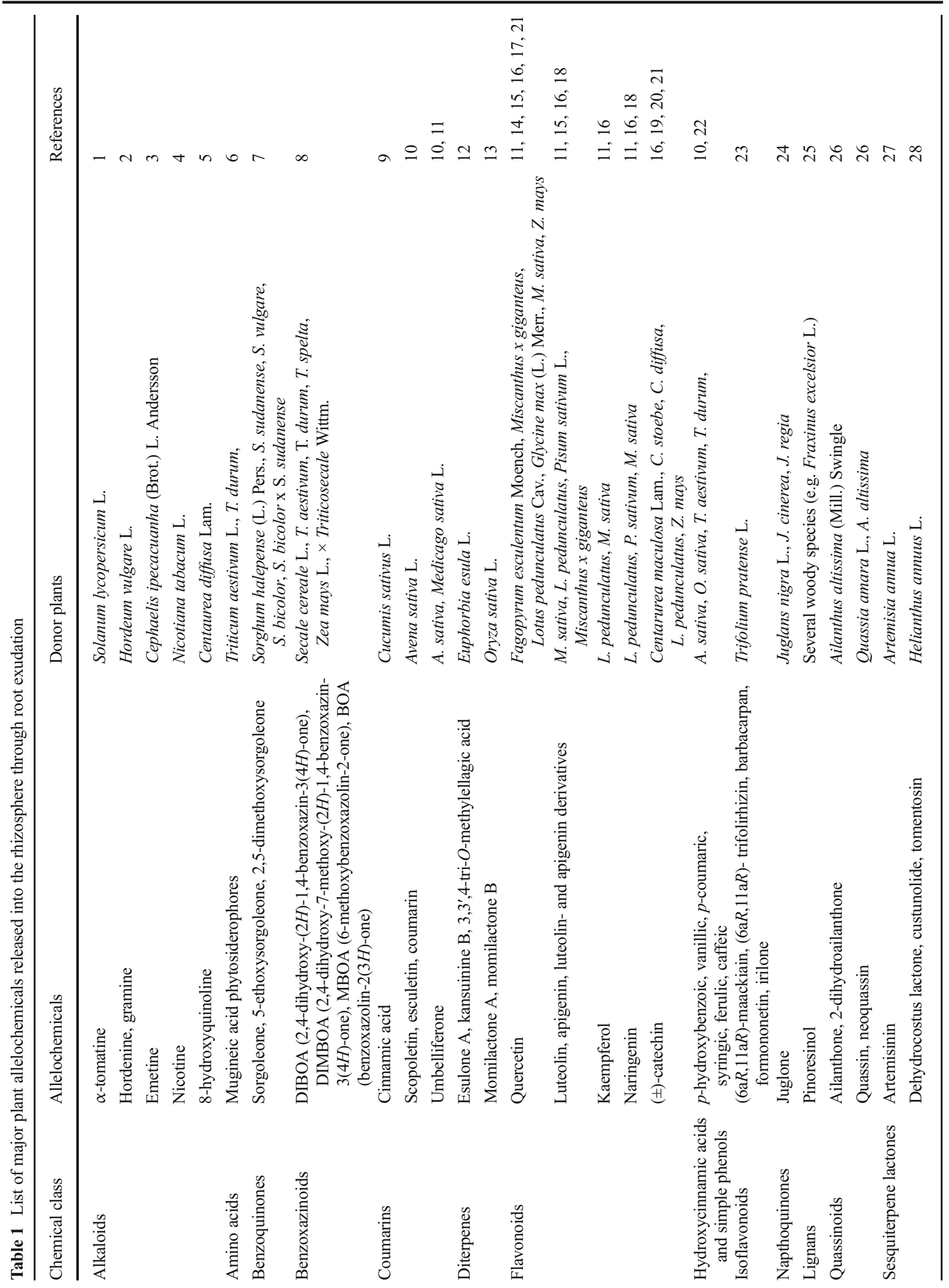


contrary, influence internal metabolic processes (Uren 2000). Root exudates, which are a part of rhizodeposits, are also classified into low- and high-molecular weight compounds. Low- $\mathrm{M}_{\mathrm{r}}$ compounds include amino acids, organic acids, sugars, phenolics, and other secondary metabolites and represent the majority of root exudates, whereas high- $\mathrm{M}_{\mathrm{r}}$ compounds are represented by proteins, terpenoids, vitamins and polysaccharides (primarily mucilage) (Badri and Vivanco 2009; Bais et al. 2006). A list of root exudates has been exhaustively reviewed in previous works (Bertin et al. 2003; Rovira 1969; Uren 2000). In literature, many evidences have been reported on the root exudation of allelochemicals, suggesting how this pathway of release represents the largest source of plant allelochemicals into the rhizosphere. Major allelochemicals released by plants through root exudation are listed in Table 1.

Cellular transport of root exudates and allelochemicals

For a long time, root exudation has been considered solely a passive process. Nowadays, we know that plants are able to actively secrete metabolites into the environment. The three passive pathways by which plant living roots release secondary metabolites out of the cells are diffusion, ion channels and vesicle transport (Bertin et al. 2003; Neumann and Romheld 2001), while the active secretion process involves the utilization of specific membrane-bound transport proteins embedded in the plasma membrane (Fig. 4). Since most allelochemicals are large charged molecules and ions, they are too polar to directly diffuse through the cell membrane. Therefore, they need other transport pathways such as subcellular vesicles, channels and transporters, also known as carriers (Taiz and Zeiger 2002; Walker et al. 2003).

Among plant carriers there are the ATP-binding cassette $(\mathrm{ABC})$ transporters, the multidrug and toxic compound extrusion (MATE) transporters, the aluminiumactivate malate transporter (ALMT), and the major facilitator superfamily (MFS) (Weston et al. 2012). Membrane-protein transporters are the most important secretion process involving the exudation of plant allelochemicals from the root into the rhizosphere. Some examples are provided by benzoxazinoids from the Poaceae family, artemisinin, juglone and several phenolics and alkaloids. The intracellular transport of flavonoids, one of the most important chemical class comprising allelochemicals, and their exudation into the 
rhizosphere can occur via transporters of the $\mathrm{ABC}$ (Buer et al. 2007) or MATE (Zhao and Dixon 2009) families. The ABC transporters are an ancient superfamily of proteins, classified into 13 subfamilies, which can be found in all phyla (Higgins 1992). They use the hydrolysis of ATP to power the transport of a broad range of compounds across cell membranes. Most of them are localized in the vacuolar membrane and play a wide variety of physiological roles such as root exudation (Badri et al. 2008; Sugiyama et al. 2007). Sugiyama et al. (2007) indicated an ATP-dependent manner transport for the isoflavonoid ginestenin from soybean root vesicles. Many poaceae species utilize YS1 (yellow stripe 1) and YS1-like (YSL) protein transporters to secrete and transport mugineic acid family phytosiderophores under Fe-deficiency (Senoura et al. 2017). MATE transporters, which are widely distributed in all kingdoms of living organisms, use an electrochemical gradient of $\mathrm{H}^{+}$or $\mathrm{Na}^{+}$to transport secondary metabolites from cells (Omote et al. 2006). They are responsible for multidrug resistance (e.g. aluminium or tetramethylammonium tolerance) through the exudation of toxic metabolites and xenobiotics from cells. The ALMT genes are typical of plants and confer aluminium resistance by facilitating the efflux of malate anions (Ryan et al. 1995). Sasaki et al. (2004) found that the wheat gene ALMT1 and heterologous expression of ALMT1 in Xenopus oocytes, rice and cultured tobacco

\section{Cytosol}

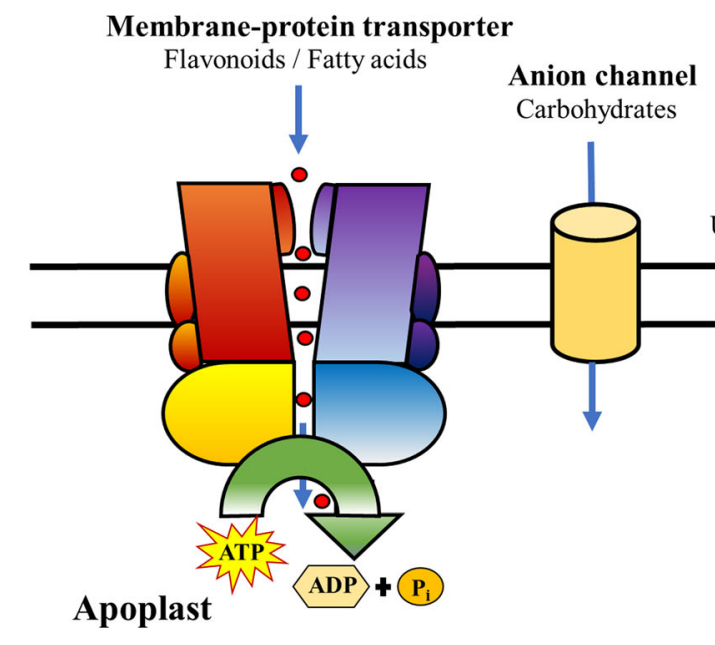

Fig. 4 Pathways of release of root exudates into the rhizosphere through the plant cell membrane. Living plant roots can release secondary metabolites out of the cell primarily through three passive processes (diffusion, ion channels and vesicle transport)

\section{Cytosol}

cells, encode a membrane protein for the efflux of malate from the root apices, avoiding aluminium toxicity in acid soils. The MFS proteins are the largest family of secondary transporters found in all phyla (Yan 2013). They transport a wide spectrum of compounds (e.g. ions, carbohydrates, lipids, amino acids and peptides, nucleosides, etc.) across membranes.

The transport of high- $\mathrm{M}_{\mathrm{r}}$ compounds via root cells can also be mediated by vesicles or specialized organelles (Battey and Blackbourn 1993). Vesicle transport of secondary metabolites such as allelochemicals from the site of synthesis to storage compartments and to cell membrane for efflux, has been described in detail (Field et al. 2006; Robatzek 2007). Most likely, it is related to the necessity of separating from the cytoplasm and safely transporting allelochemicals, most of which are cytotoxic for the host cells (Weston et al. 2012). Flavonoids (e.g. luteonin, catechin, etc.), synthesized on the surface of endoplasmatic reticulum (ER), are separate from the ER and transported by ERoriginating vesicles that fuse to the cell membrane and release their contents (Walker et al. 2003). Bock et al. (2002) suggested a vesicle-mediated mechanism for the transport of the alkaloid berberine in different Berberis species and Papaver somniferum L. Moreover, it is thought that sorgoleone, the toxic benzoquinone produced by Sorghum spp., is synthesized on ER and Golgi bodies, transported through subcellular trafficking or to 
the plasma membrane for efflux, and exuded from living root hairs (Czarnota et al. 2003a; Grotewold 2001; Weston et al. 2012). Besides, vesicle transport is a defence mechanism for plants, which react to pathogen infection by trafficking antimicrobial compounds to the site of infection through subcellular-membrane vesicles and organelles such as the Golgi or ER-vesicles.

Membrane-protein transporters and subcellular vesicles are the most important mechanisms involved in the translocation of allelochemicals across cell membranes into the rhizosphere. In addition to these processes, plants possess other passive pathways for the release of root exudates and secondary metabolites, even if little used because most of allelochemicals are complexcharged molecules. Diffusion involves electrochemical positive concentration gradients between the cytoplasm of root cells and the soil which support the release of low- $\mathrm{M}_{\mathrm{r}}$ compounds such as sugars, amino acids and phenolics that, in the cytoplasmic $\mathrm{pH}$ of root cells, are negatively charged, and the uptake of cations from the outside of the cell (Bertin et al. 2003). Another diffusion process is by aquaporins, also known as water channels. They are integral membrane proteins that facilitate the transport of water, and in some cases, small neutral molecules such as glycerol and urea (aquaglyceroporins) across cell membranes. Aquaporin permeability is regulated by phosphorylation (Assmann and Haubrick 1996).

Ion channels are membrane protein complexes allowing the diffusion of ions and charged molecules across the cell membrane. This pathway of release does not need the input of ATP, but works through an electrochemical gradient. Ion channels are ion selective because they are able to discriminate between size and charge of molecules. Anion channels are involved in the released of carbohydrates, specifically organic acids such as citrate, malate or oxalate into the rhizosphere (Jones and Darrah 1995; Walker et al. 2003). For example, maize (Zea mays L.), wheat (Triticum aestivum L.) and other plant species exudate citric, malic, and related organic acids through ion channels in response to high $\mathrm{Al}^{3+}$ concentrations (Ma et al. 2001).

\section{Interactions between allelochemicals and soil characteristics}

The behaviour of allelochemicals in the soil is fundamental for the determination of their phytotoxic effects, particularly the adsorption-desorption balance, which influences the concentration of allelochemicals in soil water (Kobayashi 2004). This balance is very dynamic and reversible. It is closely influenced by soil physical (texture, structure, organic matter content, moisture and aeration), chemical (reaction, ion exchange capacity, nutrient dynamics, $\mathrm{O}_{2}$ and $\mathrm{CO}_{2}$ concentrations), and biological characteristics (soil microorganisms). Likewise, plants can modify their rhizosphere characteristics through ion, $\mathrm{H}_{2} \mathrm{O}$ and $\mathrm{O}_{2}$ uptake and rhizodeposition (Darrah 1991). A summary on the effects of soil characteristics on allelochemicals phytotoxicity is reported in Table 2. It is important to underline that the level of phytotoxicity is not affected only by a single soil characteristic. On the contrary, these are closely linked to each other and exert a multiple-effect on retention, transport and transformation processes of allelochemicals in soil.

\section{Soil texture}

Soil texture refers to the size of particles making up a soil and to the particle-size distribution into textural classes. It has considerable influence on water holding capacity, soil moisture, aeration and temperature, soil reaction, soil microbial communities, ion exchange capacity, nutrient retention and soil porosity, etc. Clay minerals such as kaolinites, vermiculites, smectites, etc. are the active portion of a soil, because chemical reactions occur on their surface. Soil texture closely affects allelochemicals leaching and, consequently, their phytotoxic effects (de Albuquerque et al. 2011). Besides, since clay minerals differ greatly from each other, also the typology of clay influences the availability of allelochemicals. For example, smectite-dominated soil such as Vertisols, very rich in montmorillonites (expanding 2:1 silicate clays), have the highest specific surface area, ion exchange capacity, water retention capacity and, thus, the strongest retention power towards allelochemicals. On the contrary, in soils dominated by nonexpanding 1:1 silicate clays such as kaolinites, which exhibit opposite characteristics compared to montmorillonites, the retention of allelochemicals is very low. Inderjit and Dakshini (1994) reported different amounts of Pluchea lanceolata (DC.) Oliv. \& Hiern leaf leachates in four soil types (sandy loam, clay loam, silty loam, and sand). Jennings and Nelson (1998), studying in columns the influence of soil texture on alfalfa autotoxicity, found that chemicals moved through the 
Table 2 Positive (+) and negative (-) effects of soil characteristics on the allelochemicals phytotoxicity in soil

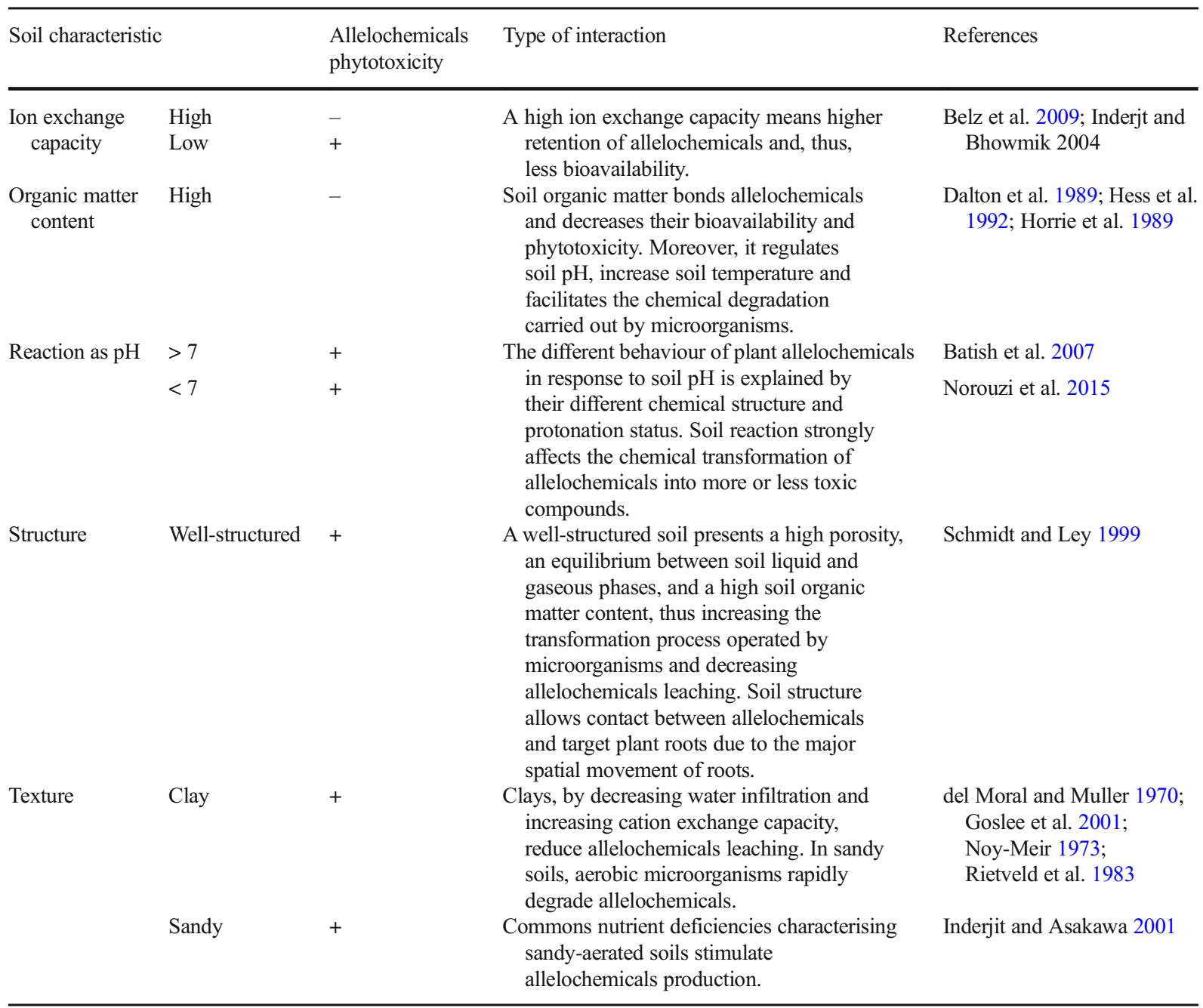

Sarpy fine sandy loam (mixed, mesic Typic Udipsamments) faster than through the Carlow silty clay loam (fine, smectitic, mesic Vertic Endoaquulls). According to del Moral and Muller (1970), Eucalyptus camaldulensis Dehnh. is more toxic on fine than on coarse soils. This is probably due to the high evaporation that concentrates allelochemicals near the soil surface, and to the low infiltration that prevents allelochemicals from leaching out of the rooting zone (Noy-Meir 1973). Moreover, Rietveld et al. (1983) stated that in well-aerated and drained sandy soils, the microbial degradation of toxic compounds operated by aerobic microorganisms is accelerated. Goslee et al. (2001) reported that Acroptilon repens (L.) DC. became dominant faster and reached a higher proportion of the total biomass on fine- than on coarse-textured soils. El-
Darier et al. (2014) found that Medicago sativa L. crude powder reduced the accumulation of total stem, leaf and root dry matter of Vicia faba L. more so in clay than in sandy soils. On the contrary, Bouhaouel et al. (2018) pointed out that Hordeum vulgare L. subsp. vulgare allelochemicals exuded by roots were more toxic in a sandy substrate. Also Shaukat et al. (2003) reported higher phytotoxic effects of Conyza canadensis L. shoot aqueous extracts in amendment sandy soils, followed by loamy sand and sandy loam soils, probably to the minimal adsorption on soil particles and to the low microbial and chemical degradation. According to Inderjit and Asakawa (2001), the higher inhibitory activity of plants in sandy soil is due to the nutrient deficiency characterizing these kinds of substrates, which stimulates the production and release of allelochemicals. 
Results on the influence of soil texture on allelochemicals phytotoxicity contradict each other, since some authors found higher inhibitory activity in clay soils while others in sandy substrates. We consider the former hypothesis more realistic. In fact, clays, thanks to their high surface area and negative surface charges decrease water infiltration, increase cation exchange capacity and, thus, reduce allelochemicals leaching, which is the most important factor affecting their phytotoxic behaviour. Moreover, in clay soils the aeration is lower than in sandy ones, and therefore aerobic microorganisms slowly degrade allelochemicals. However, most experiments in literature were carried out in artificial substrates under laboratory conditions. The setup of long-term field experiments plays a key role for a better understanding on the effects of soil texture on allelochemicals phytotoxic potential.

\section{Soil structure}

Soil structure is the arrangement and organization of soil particles in the unit of soil particle density. Pagliai and Vignozzi (2002) defined soil structure as "the combination of different types of pores". Soil particles, particularly silicate clay, tend to bind together in aggregates. Soil aggregation generates porosity variability and regulates the ratios between solid, liquid and gaseous soil phases. Many agronomic functions depend on pore size distribution and shape (Ringrose-Voase and Bullock 1984). Rhizodeposition promotes the formation of aggregates both directly and indirectly. Directly thanks to the adsorption of rhizodeposits (e.g. ions such as $\mathrm{Ca}^{2+}$, $\mathrm{Fe}^{2+}, \mathrm{Al}^{3+}, \mathrm{K}^{+}$, as well as mucillages and several organic acids) with colloids, and indirectly since root exudates are used as food by microorganisms, which play a key role in the aggregation process. Likewise, the availability of allelochemicals in the soil is affected by soil structure (Schmidt and Ley 1999), mainly the retention process. A well-structured soil, for example, has a high cation exchange capacity, which decreases the leaching of allelochemicals operated by water. The size and shape of soil pores affect allelochemicals adsorption considerably. Indeed, Jardine et al. (1990), stated that solute concentrations in general are correlated to pore size. In particular, micropores have a greater retention capacity than meso- and macropores (Blum 2006). Soil structure can also affect the transformation process carried out by microbial communities since it regulates soil porosity, the equilibrium between soil liquid and gaseous phases, as well as soil organic matter content. The oxidation/ reduction potential too, also known as redox potential, depends closely on the oxygen level in soil (Weil and Brady 2017). Furthermore, soil structure affects the release and spatial disposition of allelochemicals in soil by influencing the explorable depth by roots.

Although soil structure is a key soil characteristic, its interactions with allelochemicals have been little investigated by the scientific community. Therefore, major efforts are needed to investigate the relationship between size and distribution of pores and channels with retention and transport processes of allelochemicals in the soil.

\section{Soil organic matter content}

Soil organic matter (SOM) represents the organic fraction of the soil solid phase and comprises about 2-3\% of the total weight. SOM includes a complex mixture of many substances that, for simplicity, can be classified into five main classes: 1) edaphon (all the living organisms), 2) "fresh" organic matter, (e.g. plant litter and residues, root and leaf exudates, remains of soil organisms), 3) "labile" (= easily altered) humus (SOM with a carbon/ nitrogen ratio $(\mathrm{C} / \mathrm{N})$ of $15-20,4)$ humus (SOM in which the humification process completely occurred and characterised by a $\mathrm{C} / \mathrm{N} \approx 10$ ) and 5 ) DOM (dissolved organic matter in solution that passes through a $0.45 \mu \mathrm{m}$ filter.)

There is a quite lot evidence on the influence of SOM on the availability of allelochemicals in soil, particularly on the adsorption-desorption process (Fageria 2012; Inderjit 2001; Vogel and Dawson 1985). SOM, thanks to its high surface area and negative surface charges, contributes to enhance the cation exchange capacity in the same way as clays. Humin, humic and fulvic acids are estimated to account from 20 to $80 \%$ of the cation exchange capacity (Wagner and Wolf 1998). On one hand, SOM can bond allelochemicals making them inactive and/or decreasing their bioavailability and phytotoxicity (Dalton et al. 1989). For example, Horrie et al. (1989) observed that Cytisus scoparius (L.) Link allelochemicals concentration was higher in soils with low SOM, inhibiting lettuce seedling emergence, while decreasing in soils with high SOM. In hot-semiarid soils, which generally have a low SOM $(<1 \%)$, allelochemicals adsorption is low, promoting the spread and diffusion of allelopathic plants such as Rhaponticum repens (L.) Hidalgo and Centaurea 
maculosa Lam. (Grossl 2008). Kulmatiski and Beard (2006) indicated that C. maculosa diffusion in the field was lowered by adding activated carbon into the soil thanks to the sequestration of $( \pm)$-catechin. The activity of sorgoleone was reported to be decreased due to the high retention to SOM (Hess et al. 1992). On the other hand, allelochemicals, as well as heavy metals and cations such as $\mathrm{Fe}^{3+}, \mathrm{Al}^{3+}, \mathrm{Mn}^{2+}$ and $\mathrm{Ca}^{2+}$, can be chelated by SOM in order to prevent their oxidation and increase their efficiency (Cheng 1989; Jabran et al. 2013; Marschner 1995). Moreover SOM, particularly humus, tends to give a darker color to $\mathrm{O}$ and A horizons, which allows increasing the solar radiation absorption and, thus, the soil temperature (Blum 2006; Fang et al. 2005). A higher soil temperature means a greater microbial activity and, consequentially, more rapid transformation processes of allelochemicals. SOM also exerts a buffer power on soil $\mathrm{pH}$ by avoiding excesses of acidity or alkalinity (Jansen van Rensburg et al. 2009; McCauley et al. 2009).

\section{Soil reaction}

Soil reaction represents the degree of acidity, alkalinity or neutrality of the soil aqueous extract and it is expressed as $\mathrm{pH}$. Soil reaction can affect the growth of both crop plants and weeds (Joe and Allen 1980), the life of microorganisms (Rousk et al. 2009) and, chiefly, the availability of nutrients (Härdtle et al. 2004). The influence of soil $\mathrm{pH}$ on allelochemicals is widely reported in literature (Batish et al. 2007; Borek et al. 1994; Norouzi et al. 2015). Soil reaction is closely involved in the chemical transformation of allelochemicals into more or less toxic compounds. Borek et al. (1994) found that the enzymatic decomposition of sinigrin, a well know glucosinate produced by Brassica spp., operated by the enzyme myrosinase $(\beta$-thioglucoside glucohydrolase) was highly dependent on soil reaction. In particular, allylnitrile production was highest at $\mathrm{pH}$ 3.0 , while at higher $\mathrm{pH}$ values $(\approx 6.0)$ allyl isothiocyanate was the only sinigrin decomposition product. Also, the degradation processes of benzoxazinoids in soil are governed by the $\mathrm{pH}$ level. Niemeyer et al. (1982) documented an asymmetric bell-shaped curve of DIMBOA decomposition rates under a $\mathrm{pH}$ range, with a maximum around pH 9.0. Dayan (2006) reported a higher production of sorgoleone in Sorghum bicolor (L.) Moench seedlings grown in buffers as the $\mathrm{pH}$ decreased. Batish et al. (2007), studying the effect of Chenopodium murale L. residues on growth, nodulation and macromolecule content of chickpea (Cicer arietinum L.) and pea (Pisum sativum L.), pointed out that the $\mathrm{pH}$ of the residue-amended soil changed from neutral (6.85) to slightly alkaline (7.47) with 5-40 $\mathrm{g}$ residue $\mathrm{kg}^{-1}$ soil. The observed reduction in root, shoot length and dry matter accumulation in amended soils was accompanied by an increase in the SOM, electrical conductivity and available nitrogen. Norouzi et al. (2015) reported that the allelopathic effects of powdered below- and aboveground organs of alfalfa (M. sativa), sorghum (S. bicolor) and tobacco (Nicotiana tabacum L.) on several weeds increased in response to lower soil $\mathrm{pH}$ levels. Likewise, plants are able to modify rihizosphere $\mathrm{pH}$ through the exudation of allelochemicals, principally with the aim of increasing nutrient availability.

Ion exchange capacity

In soil, both mineral (e.g. clay minerals as well as Fe-, Al- and Mn-oxides) and organic (humus) colloids have negative or positive surface charges allowing the attraction with cations and anions (Lavelle and Spain 2001). The ion exchange capacity represents the measurement of the total absorbed/desorbed ions per unit mass of soil. It is highly influenced by soil texture, type of clays, SOM, soil reaction, the kind and concentration of ions and the presence of ions of opposite charge. For example, the negative charges are more abundant in alkaline or sub-alkaline soil of semiarid regions, rich in 2:1 silicate clays, while positive charges predominate acid soils rich in 1:1 clays and Al- and Fe-oxides (Weil and Brady 2017). In the former, there is a prevalence of cation adsorption, in the latter that of anion. The ion exchange capacity includes the cation exchange capacity (CEC) and the anion exchange capacity (AEC). CEC is the number of readily exchangeable cations (e.g. $\mathrm{Na}^{+}$, $\left.\mathrm{H}^{+}, \mathrm{K}^{+}, \mathrm{NH}_{4}^{+}, \mathrm{Ca}^{2+}, \mathrm{Mg}^{2+}, \mathrm{Mn}^{2+}, \mathrm{Al}^{3+}, \mathrm{Fe}^{3+}\right)$ neutralizing negative charges on soil surfaces (Rhoades 1982). Soils can have CEC values between 6 and $>40$ meq 100 $\mathrm{g}^{-1}$. Generally, CEC is higher with high $\mathrm{pH}$ levels and clay soils. AEC is the same of CEC, expressed in terms of anions (e.g. $\mathrm{H}_{2} \mathrm{PO}_{4}{ }^{-}, \mathrm{NO}_{3}{ }^{-}, \mathrm{Cl}^{-}, \mathrm{HPO}_{4}{ }^{--}, \mathrm{SO}_{4}{ }^{--}, \mathrm{PO}_{4}{ }^{-}$), principally operated by $\mathrm{Fe}-$ and $\mathrm{Al}$-oxides. AEC and CEC are inversely proportional. They are very important for the adsorption/desorption balance and, thus, for the retention and transport processes by affecting allelochemicals leaching and availability. Inderjit and Bhowmik (2004), evaluating the growth of cucumber 
Table 3 The role of soil allelochemicals in plant nutrition.

\begin{tabular}{|c|c|c|}
\hline Nutrient soil condition & Allelochemicals role & References \\
\hline Fe-deficiency & $\begin{array}{l}\text { Phytosiderophores exudation from poaceae plant roots, } \\
\text { formation of } \mathrm{Fe}^{3+} \text {-phytosiderophores complexes, } \\
\text { transport with YS1/YSL protein transporters across } \\
\text { plasma membranes and improve available } \mathrm{Fe}^{2+} \text { for plant. }\end{array}$ & $\begin{array}{l}\text { Meda et al. 2007; Senoura } \\
\text { et al. 2017; Ueno et al. } 2007\end{array}$ \\
\hline Micronutrients deficiency & $\begin{array}{l}\text { Exudation of mugineic acid family phytosiderophores to } \\
\text { chelate metallic micronutrient and increase their solubility, } \\
\text { availability and transport. }\end{array}$ & $\begin{array}{l}\text { Suzuki et al. 2016; Tsai and } \\
\quad \text { Schmidt } 2017\end{array}$ \\
\hline P-deficiency & $\begin{array}{l}\text { Organic acids secretion to acidified rhizosphere, block } \\
\text { phosphate from } \mathrm{Ca}^{2+}, \mathrm{Fe}^{3+} \text { and } \mathrm{Al}^{3+} \text {, and improve } \\
\text { available } \mathrm{P} \text { for plant. }\end{array}$ & $\begin{array}{l}\text { Dakora and Phillips 2002; } \\
\text { Wang et al. } 2014\end{array}$ \\
\hline $\mathrm{Al}^{3+}$ toxicity & $\begin{array}{l}\text { Organic acids (e.g. citrate, malate, oxalate, etc.) and } \\
\text { flavonoids exudation to chelate and detoxify soil aluminium. }\end{array}$ & $\begin{array}{l}\text { Kochian et al. } 2004 ; \\
\quad \text { Valentinuzzi et al. } 2016\end{array}$ \\
\hline \multirow[t]{2}{*}{ High nitrification rate } & $\begin{array}{l}\text { Exudation of biological nitrification inhibition substances } \\
\text { (BNIS) such as phenolics and terpenoids to inhibit the } \\
\text { ammonium-oxiding bacteria enzymes. }\end{array}$ & Rice 1984; Subbarao et al. 2009 \\
\hline & Allelochemicals exudation to inhibit soil $\mathrm{N}$ mineralization. & Dietz et al. 2013 \\
\hline High $\mathrm{N}$ volatilization losses & $\begin{array}{l}\text { Allelochemicals exudation to inhibit the denitrification } \\
\text { process of } \mathrm{NO}_{3}^{-} \text {into } \mathrm{N}_{2} \mathrm{O} \text { and } \mathrm{NO} \text {. }\end{array}$ & Ma 2005 \\
\hline Nutrient availability and uptake by plant & $\begin{array}{l}\text { Allelochemicals exudation to depolarize of cell membrane } \\
\text { electrical potential, inhibit mitochondrial oxidative } \\
\text { phosphorylation and electron transport, and alter membrane } \\
\text { permeability. }\end{array}$ & Balke 1985 \\
\hline
\end{tabular}

(Cucumis sativus L.) and radish (Raphanus sativus L.) in two soils amended with different amounts of benzoic acid, reported a higher sorption of benzoic acid in the soil with higher clay content, SOM and CEC. Belz et al. (2009) found that parthenin degradation, which is the allelochemical responsible for the invasive success of Parthenium hysterophorus L., is favoured in clay soils with high CEC. These two examples showed a lower allelopathic potential correlated to high CEC, probably due to the strong retention forces that prevent allelochemicals from making contact with target plants.

\section{Mineral nutrients availability}

Root exudation of allelochemicals into the rhizosphere exerts a strong influence on nutrient release, solubilization, mobilization and uptake by plants (Jabran et al. 2013; Yu and Matsui 1997) (Table 3). It is known that mineral availability not only depends on its concentration, but also on mineral form. In the soil, although a mineral is relatively abundant, it can be present in an unavailable form for the plant. This phenomenon is mainly correlated to the soil reaction. For example, $\mathrm{P}$ and $\mathrm{Fe}$ become insoluble in high $\mathrm{pH}$ levels in presence of calcium carbonate $\left(\mathrm{CaCO}_{3}\right)$, while $\mathrm{Al}^{3+}$ and $\mathrm{Mn}^{2+}$ precipitate in highly acid soils, often becoming toxic. Under nutrient deficiency, many plant species exudate allelochemicals in order to increase their availability (Jones and Darrah 1994). One of the most important tools utilized by plants to increase their nutrition efficacy is the alteration of rhizosphere $\mathrm{pH}$ levels. According to Bais et al. (2006), root exudates can increase or decrease soil nutrient availability through two mechanisms: phytosiderophores (PS) and organic acid secretion. Although these secondary metabolites are not allelochemicals sensu stricto, most authors suggest that in addition to the phytotoxic effects to the target plants, allelochemicals could induce a stimulatory effect on the donor plant in terms of resource acquisition (Rice 1984; Tharayil et al. 2009). For this reason, such PS and organic acids are considered putative allelochemicals within the so-called "allelopathy-paradigm".

Several poaceae plants, such as wheat, sorghum, oat and barley, under metallic micronutrient deficiency (mainly $\mathrm{Zn}^{2+}, \mathrm{Mn}^{2+}, \mathrm{Fe}^{3+}$ and $\mathrm{Cu}^{2+}$ ) exudates metalchelating amino acids called phytosiderophores (Sugiura and Nomoto 1984). The most common example of plant PS utilization refers to Fe-deficiency. PS act as chelators by forming organic complexes with $\mathrm{Fe}^{3+}$, which is precipitated and insoluble in soils, and taking up the $\mathrm{Fe}^{3+}$-phytosiderophore complex by $\mathrm{Fe}$ 
deficiency-inducible transporters of the YS1/YSL protein family, thus increasing its solubility and transport (Curie et al. 2001; Meda et al. 2007; Ueno et al. 2007). PS release and FePS uptake are under different genetic control among poaceae species (Römheld and Marschner 1990). Recently, Suzuki et al. (2016) reported the detection of 2'-deoxymugineic acid (DMA), a compound belonging to the mugineic acid family phytosiderophores (MAs) in the olive (Olea europaea L.) xylem sap, indicating for the first time the presence of PS in a non-graminaceous dicot plant. Nozoye et al. (2017) found that the biomass-energy crop Erianthus ravennae (L.) Beauv. secreted mugineic acid (MA) and deoxymugineic acid (DMA) under soil Fe-deficiency. Apart from PS in poaceae plants, dicots are also able to exudates phenolics compounds such as coumarins that work as metallic micronutrient chelators (mainly $\mathrm{Al}^{3+}$, $\mathrm{Fe}^{3+}$ and $\mathrm{Mn}^{2+}$ ) to avoid their deficiency in soil (Dakora and Phillips 2002; Tsai and Schmidt 2017).

Another important tool enabling many plants to improve mineral nutrient acquisition is organic acid secretion. This mechanism, contrary to PS secretion, is more importance for $\mathrm{P}$ availability than for micronutrients (Dakora and Phillips 2002). In soils, P availability depends on $\mathrm{pH}$ level (it is very low in alkaline soils), concentrations of anions that compete with $\mathrm{P}$ ions for ligand exchange reactions and concentrations of metals $\mathrm{Ca}^{2+}, \mathrm{Fe}^{3+}$ and $\mathrm{Al}^{3+}$ that can co-precipitate with $\mathrm{P}$ ions (Hinsinger 2001). However, in the rhizosphere P availability is higher thanks to the localized acidification caused by $\mathrm{CO}_{2}$ or $\mathrm{HCO}_{3}{ }^{-}$secretion and to the exudation of organic acids such as malic or citric acids (Hoffland et al. 1989). Plant roots, under P- or Fe-deficiency, release citrate and other dicarboxylates to block phosphate from $\mathrm{Ca}^{2+}, \mathrm{Fe}^{3+}$, or $\mathrm{Al}^{3+}$ precipitates and release available P into the soil (Bais et al. 2006; Meda et al. 2007). The most widely known example of rhizosphere acidification due to allelochemicals exudation is provided by Lupinus albus L., which forms proteoid roots under P-deficiency in order to exudate a large amount of citrate and increase P solubilization (Johnson et al. 1996; Wang et al. 2014). Nevertheless, organic acid secretion by plant root is helpful in response to elevated $\mathrm{Al}^{3+}$ concentrations in the soil solution and as protection from $\mathrm{Al}^{3+}$ toxicity (Kochian et al. 2004). The Alinduced organic acid secretion is species-specific, however citrate was found to be the most effective Aldetoxifying compound among different species (Kochian et al. 2004). Valentinuzzi et al. (2016) reported that $L$. albus exudes citrate and flavonoids in response to $\mathrm{Al}^{3+}$ toxicity. The mechanisms of $\mathrm{Al}^{3+}$ tolerance and $\mathrm{P}$ acquisition due to organic acid secretion into the rhizosphere are often linked because citrate, malate, oxalate, etc. chelate aluminium and mobilize phosphates (Chen et al. 2017).

Allelochemicals released by plants into the soil affect several phases of soil nitrogen cycle. One of the most important problems associated with intensive agriculture is related to the environmental pollution caused by nitrogen leaching in groundwater. $\mathrm{N}$ leaching losses are estimated in a range of 20-100 kg ha ${ }^{-1}$ year $^{-1}$, depending on season and rainfall regime as well as on soil texture. The nitrification process consists in transforming ammoniacal $\mathrm{N}\left(\mathrm{NH}_{4}{ }^{+}\right)$into nitric $\mathrm{N}\left(\mathrm{NO}_{3}{ }^{-}\right)$through two phases:

1) $\mathrm{NH}_{4}{ }^{+}$oxidation to nitrite $\left(\mathrm{NO}_{2}{ }^{-}\right)$carried out by the bacteria genera Nitrosomonas, Nitrosococcus and Nistrosospira (Teske et al. 1994);

2) $\mathrm{NO}_{2}^{-}$oxidation to nitrate $\left(\mathrm{NO}_{3}{ }^{-}\right)$operated by the Nitrobacter genus (Both et al. 1992).

The regulation of nitrification, therefore, plays a key role in improving $\mathrm{N}$-use efficiency in sustainable agriculture. It has been observed how different kinds of plant allelochemicals such as phenolics or terpenoids act as biological nitrification inhibition substances (BNIS) through the inhibition of the activities of enzymes (e.g. ammonium mono-oxygenase, hydroxylamine oxidoreductase, etc.) of ammonium-oxiding bacteria (Rice 1984; Subbarao et al. 2009). Dietz et al. (2013) indicated that Plantago lanceolata L. allelochemicals such as aucubin, catalpol, and verbascoside, suppressed soil $\mathrm{N}$ mineralization due to the incorporation of leaf material into the soil. The utilization of BNIS could be an important tool in improving $\mathrm{N}$-use efficiency of $\mathrm{N}$ fertilizers in agroecosystems by decreasing the nitrification rate (Jabran et al. 2013). Moreover, allelochemicals can reduce $\mathrm{N}$ volatilization losses by affecting the denitrification process of $\mathrm{NO}_{3}{ }^{-}$into $\mathrm{N}_{2} \mathrm{O}$, as reported by $\mathrm{Ma}$ (2005) for wheat allelochemicals.

In addition to the increase of nutrient solubilization, availability and use efficiency, allelochemicals generally decrease or inhibit mineral uptake by plants (Jabran et al. 2013). Several experiments demonstrated the inhibition of nutrient absorption in plants grown in association with other plants, due to the addition of specific 
allelochemicals in the nutrient solution (Abenavoli et al. 2010) or with plant residues and mulches leachates (Babu et al. 2013). Three main physiological processes are involved in reducing the mineral nutrient uptake (Balke 1985): 1) the depolarization of cell membrane electrical potential; 2) the inhibition of mitochondrial oxidative phosphorylation and electron transport, which means a decrease of the ATP content; 3 ) the alteration of membrane permeability. The inhibition of nutrient uptake is manifested through a reduction in mineral concentrations of plant tissues or a decrease of seedlings growth.

\section{Interaction between allelochemicals and soil microorganisms}

Allelopathy involves many kinds of interactions including plant-plant, plant-insect and plant-microorganism interactions, in which the allelopathic agent may be either the plant or the microorganism. Here we discuss only the plant-microorganism interactions with the plants as donors of allelochemicals. Plants affect and communicate with their microbial community, mainly at rhizoplane level, through the release of specific root exudates, including allelochemicals, which are an important C-source for microorganisms, determining an increasing of microbial biomass around the roots. Nevertheless, plants are able to modify the chemical composition of their root exudates once in contact with microorganisms (De-la-Peña et al. 2008), in order to either recruit beneficial bacteria or repress pathogenic microorganisms (Doornbos et al. 2012).

Many studies have been conducted on the in vitro antimicrobial activity of plant allelochemicals (Mazzaglia et al. 2018; Scavo et al. 2019a). However, the mere presence of allelochemicals in the donor plant and their antimicrobial activities in artificial medium (e.g. agar) do not demonstrate an allelopathic activity in natural conditions (Romeo 2000), because soil microorganisms consume a high quantity of organic molecules and, thus, inhibitory compounds may not accumulate at toxic levels. The microbial degradation of allelochemicals depends on the chemical nature of the considered compound, on soil texture, structure, aeration, temperature, $\mathrm{SOM}$ and $\mathrm{pH}$, as well as on the microbial species involved. For example, among different species of Cephalosporium genus (e.g. C. furcatum, C. khandalense, C. nordinii and C. roseum), C. furcatum presents the highest degrading capacity of ferulic acid (Rice 1984). Nevertheless, the seasonal variation in the microbial population may influence the availability of allelochemicals. Abbate et al. (2005), for example, studying the bacterial communities in the rhizosphere of transgenic rolABC citrange Troyer by using phenotypical testing (BIOLOG) and 16S rDNA gene-based molecular analysis (ARDRA; DGGE), found that, on one hand, the structure of such rhizosphere communities was minimally altered and, on the other, the eubacterial DGGE (denaturing gradient-gel electrophoresis) profiles reflected marked seasonal population shifts. Gyamfi et al. (2002) reported minor differences in the DGGE patterns of the eubacterial population associated with transgenic canola due to the seasonal variation. Dunfield and Germida (2003), studying the variation in the microbial community of a transgenic canola variety, found differences during the plant growing season while remaining stable after winter, concluding that the observed changes were temporary and did not persist in the next field season. Moreover, the structure of soil bacteria communities is often related to the spatial location. In particular, bacterial abundance in the rhizosphere is reported to be higher than in root-free soil (Gamalero et al. 2004; Watt et al. 2006), and rhizosphere bacterial density follows the trend: basal region $>$ bulk soil>apical region (Dennis et al. 2008). The amount of microbial species and their relative abundance within specific root zones is a poorly investigated aspect in the rhizosphere microbial ecology. This could be explained by the high heterogeneity of both abundance and distribution of rhizosphere microorganisms, which vary considerably in relation to the position along longitudinal root axes (Dennis et al. 2008). At the root base, in fact, bacterial communities have been observed to partially cover the rhizoplane, while in root apices they are present as clusters that occupy a relatively small proportion of the available root surface (Chin-A-Woeng et al. 1997). Nevertheless, each plant species cultivates a specific microbial rhizosphere community, both bacteria (Smalla et al. 2001) and fungi (Broeckling et al. 2008), and both in natural and agroecosystems (Broz et al. 2007), as reported by numerous studies carried out with the DGGE method.

The nature of plant-microorganism interaction can be either beneficial or deleterious. Positive interactions affected by plant allelochemicals are represented by symbiotic associations with mycorrhizae, rhizobia and plant growth-promoting bacteria (PGPB), while negative 
Table 4 The positive and negative role of allelochemicals in plant-soil-microorganism interactions.

\begin{tabular}{|c|c|c|}
\hline Type of interaction & Allelochemicals role & References \\
\hline \multicolumn{3}{|l|}{ Positive interactions } \\
\hline Legume-Rhizobium symbiosis & $\begin{array}{l}\text { Isoflavonoids exuded by legume roots enhance } \\
\text { the growth of rhizobial cells, their chemotaxis } \\
\text { and the transcription of nod genes. }\end{array}$ & Peters et al. 1986; Sugiyama et al. 2007 \\
\hline Arbuscular mycorrhizal associations & $\begin{array}{l}\text { Under P-deficiency, different plant species exude } \\
\text { strigolactones into the rhizosphere to stimulate } \\
\text { the hyphal branching of mycorrhizal fungi. }\end{array}$ & Akiyama et al. 2005; Buee et al. 2000 \\
\hline Plant growth-promoting bacteria (PGPB) & $\begin{array}{l}\text { Under stress conditions, plant allelochemicals } \\
\text { exuded into the rhizosphere promote and attract } \\
\text { PGPB chemotaxis on root surface. }\end{array}$ & Somers et al. 2004 \\
\hline Induced systematic resistance (ISR) & $\begin{array}{l}\text { Several PGPB species, thanks to a chemical } \\
\text { communication with plant via allelochemicals } \\
\text { exuded into the rhizosphere, induce the creation } \\
\text { of a protective biofilm on plant roots with the } \\
\text { aim of restricting pathogen access. }\end{array}$ & Bais et al. 2004b; Bakker et al. 2003 \\
\hline $\begin{array}{l}\text { Plant (semi-)volatile organic } \\
\text { compounds (VOCs) - herbivore in- } \\
\text { sects }\end{array}$ & $\begin{array}{l}\text { When insect herbivores attack a plant, their roots } \\
\text { produce different kinds of VOCs as cues for } \\
\text { natural enemies of root herbivores. }\end{array}$ & $\begin{array}{l}\text { Hiltpold et al. 2015; Vaughan et al. 2013; } \\
\text { van Dam and Bouwmeester } 2016\end{array}$ \\
\hline \multicolumn{3}{|l|}{ Negative interactions } \\
\hline \multirow[t]{2}{*}{ Parasitic plant associations } & $\begin{array}{l}\text { Under P-deficiency, mycorrhizal fungi induce } \\
\text { the secretion of strigolactones from donor } \\
\text { plant roots. These compounds stimulate the } \\
\text { colonization of host plant roots by promoting } \\
\text { hyphal branching. Strigolactones, however, at } \\
\text { the same time promote the parasitic plant infection } \\
\text { by stimulating their seed germination through } \\
\text { an increase of mitochondrial activity. }\end{array}$ & Bouwmeester et al. 2003, 2007 \\
\hline & $\begin{array}{l}\text { Strigolactone and its derivatives, at certain } \\
\text { concentrations, inhibit arbuscular mycorrhizal } \\
\text { shoot branching. }\end{array}$ & Gomez-Roldan et al. 2008 \\
\hline Plant VOCs - herbivore insects & $\begin{array}{l}\text { Certain soil insect herbivores use VOCs released by } \\
\text { plants into the rhizosphere to localize their host. }\end{array}$ & van Dam and Bouwmeester 2016 \\
\hline Quorum sensing inhibitors & $\begin{array}{l}\text { Plants can exude chemical compounds into the } \\
\text { rhizosphere to interfere and take advantage of the } \\
\text { quorum sensing capacity of bacteria. }\end{array}$ & Bais et al. 2006; Fuqua et al. 2001 \\
\hline
\end{tabular}

ones include the associations with parasitic plants, herbivores and pathogenic microorganisms (Badri and Vivanco 2009) (Table 4).

The role of allelochemicals in positive and negative plant-microorganism interactions

Positive plant-microorganism interactions include those with beneficial effects for the plant. The most important positive interaction is through mycorrhizal symbiosis. Arbuscular mycorrhizal fungi colonize the roots of a very wide range of plants in order to increase nutrient uptake, especially that of $\mathrm{P}$, and enhance the plant health. Once a chemical signal is perceived from the host plant, mycorrhizal fungi extensively invade its root tissues. P-availability is a key factor regulating the hyphal branching (Nagahashi and Douds 1999). The hyphal branching of arbuscular mycorrhizal fungi is induced and stimulated by flavonoids (Buee et al. 2000) and, mainly, strigolactones such as sorgolactone, 5deoxy-strigol and strigol (Akiyama et al. 2005). These compounds act at very low concentrations. Sorgolactone, for example, induces branching at a concentration as low as $10^{-13} \mathrm{M}$ (Besserer et al. 2006). Different plant species are reported to exude strigolactones: tomato (Solanum lycopersicum L.), sorghum (S. bicolor), maize (Z. mays), pearl millet (Pennisetum glaucum (L.) R.Br.), red clover (Trifolium pretense L.), cotton (Gossypium hirsutum L.), etc. (Awad et al. 2006; Cook et al. 1972; Rial et al. 2018). 
The legume-Rhizobium symbiosis represents another important positive plant-microorganism interaction. This kind of association is very specific and each rhizobial strain nodulates a specific host legume. Chemical compounds responsible for this interaction are isoflavonoids such as daidzein, genistenin and luteolin (Perret et al. 2000; Peters et al. 1986; Sugiyama et al. 2007), whereas rhizobia produce lipochitooligosaccharides, called $\operatorname{nod} \mathrm{D}$, to communicate with the host plant (Phillips and Tsai 1992). These compounds exuded by legume roots govern the growth of rhizobial cells, their chemotaxis as well as the transcription of nod genes.

PGPB are the rhizosphere bacteria involved in the promotion of plant growth (Compant et al. 2005). Only $1-2 \%$ of rhizosphere bacteria promote plant growth (Antoun and Kloepper 2001). The most important bacteria genera identified as PGPR are Bacillus and Pseudomonas spp. (Podile and Kishore 2006). PGPB chemotaxis on root surface is influenced by root allelochemicals in order to attract these positive rhizoacteria when the plant is under stress condition (Somers et al. 2004). PGPB can affect plant growth both indirectly and directly. The direct promotion is through the supply of nutrients and phytohormones such as auxins, cytokinins and gibberellins. The diazotroph Azospirillum, for example, aside from fixing nitrogen, secretes the above mentioned phytohormones for the host plant (Steenhoudt and Vanderleyden 2000). The indirect promotion is achieved by increasing plant defensive capacity to phytopathogenic organisms (Van Loon 2007) and tolerance to abiotic stresses. Many PGPB species cause the induced systemic resistance (ISR) in different plant species (Bakker et al. 2003), namely the creation of a protective biofilm on plant roots with the aim of restricting pathogen access (Bais et al. 2004b). ISR is an important defensive mechanism for plants not only against soilborne pathogens, but also towards aboveground pathogenic microorganisms. In certain situations, above- and belowground parts of plants communicate to respond to pathogenic attack. When insect herbivores attack a plant, their roots produce (semi-)volatile organic compounds (VOCs) belonging to terpenoids or thiophenes chemical classes (Vaughan et al. 2013) as cues for natural enemies of root herbivores (van Dam and Bouwmeester 2016). Western corn rootworm (WRC) larvae induce maize roots to secrete $(E)$ - $\beta$-caryophyllene in order to attract an entomopathogenic nematode after feeding on maize's leaves (Rasmann et al. 2005). Hiltpold et al. (2015) indicated that the water exudates secreted by $P$. sativum attract, at low concentrations, beneficial entomopathogenic nematodes and stimulate their activity, while inducing reversible quiescence at high concentrations.

Given the wide scientific literature on the in vitro antimicrobial effects of plant allelochemicals, it appears reasonable that allelochemicals exuded into the rhizosphere could play inhibitory effects against pathogenic soil microorganisms. However, the role of allelochemicals in pathogenesis of root-infecting bacteria and fungi has not been fully appreciated, probably due to the inadequate methods available for analysis (Bais et al. 2006).

The association with parasitic plants such as Striga spp. and Orobanche spp. represents the most important example of negative plant-microorganism interaction. This type of interaction is mediated by the same mechanism and chemical compounds involved in the association with arbuscular mycorrhizal fungi (Badri and Vivanco 2009). The latter process is stimulated under Pdeficiency, inducing the secretion of strigolactones from donor plant roots. These compounds stimulate the colonization of host plant roots by promoting hyphal branching (Akiyama et al. 2005). At the same time however, strigolactone and its derivatives promote the parasitic plant infection by stimulating their seed germination through an increase of mitochondrial activity (Bouwmeester et al. 2007). In addition to strigolactones, also other compounds such as isoflavonoids, sorgoleone and the sesquiterpene lactones parthenolide and 3,5dihydroxydehydrocostus-lactone have been reported to stimulate parasitic plant seed germination (Bouwmeester et al. 2003; de Luque et al. 2000). Moreover, strigolactone inhibition of arbuscular mycorrhizal shoot branching was reported (Gomez-Roldan et al. 2008).

The secretion of VOCs from plant roots can have a negative aspect. Indeed, soil herbivores seem to use VOCs to localize their host (van Dam and Bouwmeester 2016). Eilers et al. (2016) reported that Melolontha melolontha L. larvae use VOCs exuded by Taraxacum sect. Ruderalia Kirschner \& al. to found it over a distance of several centimetres. A similar behaviour was observed on other insect herbivores such as Diabrotica virgifera virgifera LeConte involving the volatile compound (E)- $\beta$-caryophyllene (Robert et al. 2012).

Certain bacteria quench pathogen quorum-sensing capacity by degrading autoinducer signals, thereby 
blocking the expression of numerous virulence genes (Morello et al. 2004). Examples of this inhibition have been found to exist in nature. Many Gram-negative bacteria utilize autoinducers such as $\mathrm{N}$-acyl homoserine lactones (AHLs) to coordinate gene expression in a population density-dependent way. At low population densities, cells produce a basal level of AHL via the activity of AHL synthase. As cell density increases, AHLs accumulate in the growth environment. When a critical threshold concentration is reached, the AHL molecule diffuses into the cell and binds to its cognate receptor, which in turn activates or represses the coordinated expression of particular sets of genes that enhance the ecological competence of the bacterium (Fuqua et al. 2001). It is possible that plants can exude chemical compounds into the rhizosphere to take advantage of this bacterial communication system (Bais et al. 2006).

\section{Future perspectives}

Plants release a wide variety of chemical compounds into the environment both as a defense mechanism against biotic or abiotic stress factors and as a tool to communicate with other plants, soil microorganisms and within the plant itself. The progress in the analysis methodologies and technical instrumentations in recent years has enabled acquiring new knowledge on this topic. A better understanding of allelochemicals behaviour in soil could positively be applied in agroecosystems for weed and pest control and applied to traditional agricultural practices under Integrated Pest and Weed Management Systems (IPMS, IWMS). Allelopathic mechanisms can be effectively exploited for agroecosystem control in different modes. The most important concern (1) the selection of smothering crops, their breeding and inclusion in crop rotations (Scavo et al. 2019b); (2) the use of their residues as living mulches, dead mulches or green manure; and (3) the selection of the most active allelopathic compounds and their use as bioherbicides (Scavo et al. 2018b, 2019c, d, e). Nevertheless, allelopathy could be applied to manage nutrient soil dynamics, enhance plant nutrient use efficiency and avoid heavy metal-toxicity phenomena. However, many aspects of these interactions are unknown. A major challenge for the scientific community is to investigate the influence of soil physical and chemical characteristics in field conditions over long-term experiments, particularly the role of soil texture and structure on allelochemicals phytotoxicity. The complex of plant-microorganism interactions in the rhizosphere represents the area requiring major studies to better understand the aboveground chemical communication and the physiological processes involved in both positive and negative interactions with microorganisms. Moreover, the knowledge on root exudates chemistry is currently high, with hundreds of allelochemicals identified in the last decades. Their transport processes through plasma membrane need more attention though, with the aim of clarifying the behaviour of allelopathic plants and controlling the genes involved for breeding programs. Given the complexity of the soil system and the considerable heterogeneity of soils in different environments, the challenge for researchers appear more tasking than in other scientific areas, and requires involving multidisciplinary research groups, with skills belonging to botany, agronomy, biology, chemistry, ecology and soil chemistry.

\section{References}

Abbate C, Ascher J, Pietramellara G, Ambrosoli R, Gennari M (2005) Analysis of bacterial communities in the rhizosphere of transgenic rolABC citrange Troyer: preliminary studies. Fresenius Environ Bull 14:867-872

Abenavoli MR, Lupini A, Oliva S, Sorgonà A (2010) Allelochemical effects on net nitrate uptake and plasma membrane H+-ATPase activity in maize seedlings. Biol Plant 54:149-153. https://doi.org/10.1007/s10535-0100024-0

Abu-Romman S (2016) Differential allelopathic expression of different plant parts of Achillea biebersteinii. Acta Biol Hung 67(2):159-168. https://doi.org/10.1556 /018.67.2016.2.4

Akiyama K, Matsuzaki K, Hayashi H (2005) Plant sesquiterpenes induce hyphal branching in arbuscular mycorrhizal fungi. Nature 435:824-827. https://doi.org/10.1038/nature03608

Aldrich RJ (1984) Weed-crop ecology: principles in weed management. Breton Publishers, North Scituate, Massachusetts, USA

Antoun H, Kloepper JW (2001) Plant growth promoting rhizobacteria. In: Brenner S, Miller JH (eds) Encyclopedia of Genetics. Academic Press, New York, pp 1477-1480

Aslam F, Khaliq A, Tanveer A, Zahir ZA, Matloob A (2016) Wheat residue incorporation modulate emergence and seedling growth of canary grass by affecting biochemical attributes and soil properties. Int J Agric Biol 18:1033-1042

Assmann SM, Haubrick LL (1996) Transport proteins of plant plasma membranes. Curr Opin Cell Biol 8:458-467. https://doi.org/10.1016/S0955-0674(96)80021-4 
Aulakh MS, Wassmann R, Bueno C, Kreuzwieser J, Rennenberg $\mathrm{H}$ (2001) Characterization of root exudates at different growth stages of ten rice (Oryza sativa L.) cultivars. Plant Biol 3:139-148. https://doi.org/10.1055/s-2001-12905

Awad AA, Sato D, Kusumoto D, Kamioka H, Takeuchi Y, Yoneyama K (2006) Characterisation of strigolactones, germination stimulants for the root parasitic Striga and Orobanche, produced by maize, millet and sorghum. Plant Growth Regul 48:221-227. https://doi.org/10.1007/s10725006-0009-3

Babu S, Rana DS, Rana KS, Prasad D (2013) Effect of sunflower stover and nutrient management on productivity and nutrient uptake pattern of pigeonpea (Cajanus cajan) in pigeonpeasunflower (Helianthus annuus) cropping system. Ind J Agron 58:35-41

Badri DV, Vivanco JM (2009) Regulation and function of root exudates. Plant Cell Environ 32:666-681. https://doi. org/10.1111/j.1365-3040.2009.01926.x

Badri DV, Loyola-Vargas VM, Broeckling CD et al (2008) Altered profile of secondary metabolites in the root exudates of Arabidopsis ATP-binding cassette transporter mutants. Plant Physiol 146:762-771. https://doi.org/10.1104/pp.107.109587

Bais HP, Park SW, Weir TL, Callaway RM, Vivanco JM (2004a) How plants communicate using the underground information superhighway. Trends Plant Sci 9:26-32. https://doi. org/10.1016/j.tplants.2003.11.008

Bais HP, Fall R, Vivanco JM (2004b) Biocontrol of Bacillus subtilis against infection of Arabidopsis roots by Pseudomonas syringae is facilitated by biofilm formation and surfactin production. Plant Physiol 134:307-319. https://doi.org/10.1104/pp.103.028712

Bais HP, Weir TL, Perry LG, Gilroy S, Vivanco JM (2006) The role of root exudates in rhizosphere interactions with plants and other organisms. Annu Rev Plant Biol 57:233-266. https://doi.org/10.1146/annurev.arplant.57.032905.105159

Bakker P, Ran LX, Pieterse CMJ, Van Loon LC (2003) Understanding the involvement of rhizobacteria-mediated induction of systemic resistance in biocontrol of plant diseases. Can J Plant Pathol 25:5-9. https://doi.org/10.1080 /07060660309507043

Balke NE (1985) Effects of allelochemicals on mineral uptake and associated physiological process ACS Symp Series 268: 161-178.

Batish DR, Lavanya K, Singh HP, Kohli RK (2007) Phenolic allelochemicals released by Chenopodium murale affect the growth, nodulation and macromolecule content in chickpea and pea. Plant Growth Regul 51:119-128. https://doi. org/10.1007/s10725-006-9153-Z

Battey NH, Blackbourn HD (1993) The control of exocitosis in plant cells. New Phytol 125:307-308. https://doi.org/10.1111 /j.1469-8137.1993.tb03883.x

Belz RG, Hurle K (2005) Differential exudation of two benzoxazinoids - One of the determining factors for seedling allelopathy of Triticeae species. J Agric Food Chem 53:250261. https://doi.org/10.1021/jf048434r

Belz RG, van der Laan M, Reinhardt CF, Hurle K (2009) Soil degradation of parthenin - Does it contradict the role of allelopathy in the invasive weed Parthenium hysterophorus L.? J Chem Ecol 35:1137-1150. https://doi.org/10.1007 /s10886-009-9698-1
Berg G, Smalla K (2009) Plant species and soil type cooperatively shape the structure and function of microbial communities in the rhizosphere. FEMS Microbiol Ecol 68:1-13. https://doi. org/10.1111/j.1574-6941.2009.00654.x

Bertin C, Yang X, Weston LA (2003) The role of root exudates and allelochemicals in the rhizosphere. Plant Soil 256:67-83. https://doi.org/10.1023/A:1026290508166

Besserer A, Puech-Pagès V, Kiefer P, Gomez-Roldan V, Jauneau A, Roy S et al (2006) Strigolactones stimulate arbuscular mycorrhizal fungi by activating mitochondria. PLoS Biol 4(7):e226. https://doi.org/10.1371/journal.pbio.0040226

Bezuidenhout SR, Laing M (2006) Allelopathy and its influence in soil system. In: Uphoff N, Ball AS, Fernandes E, Herren H, Husson O, Laing M, Palm C, Pretty J, Sanchez P, Sanginga $\mathrm{N}$, Thies J (eds) Biological approaches to sustainable soil systems, Boca Raton, FL: CRC Press, Taylor \& Francis Group, pp 231-240

Blum U (2006) Allelopathy: A soil system perspective. In: Reigosa MJ, Pedrol N, González L (eds) Allelopathy: a physiological process with ecological implications, Springer, pp 299-340. https://doi.org/10.1007/1-4020-4280$9 \_14$

Blum Ū, Shafer SR, Lehman ME (1999) Evidence for inhibitory allelopathic interactions involving phenolic acids in field soils: concepts vs. an experimental model. Crit Rev Plant Sci 18: 673-693. https://doi.org/10.1080/07352689991309441

Bock A, Wanner G, Zenk MH (2002) Immunocytological localization of two enzymes involved in berberine biosynthesis. Planta 216:57-63. https://doi.org/10.1007/s00425-0020867-5

Borek V, Morra MJ, Brown PD, McCaffrey JP (1994) Allelochemicals produced during sinigrin decomposition in soil. J Agric Food Chem 42:1030-1034

Both GJ, Gerards S, Laanbroek HJ (1992) Kinetics of nitrite oxidation in two Nitrobacter species grown in nitritelimited chemostats. Arch Microbiol 157:436-441. https://doi.org/10.1007/BF00249101

Bouhaouel I, Gfeller A, Boudabbous K, Fauconnier ML, Amara HS, du Jardin P (2018) Physiological and biochemical parameters: new tools to screen barley root exudate allelopathic potential (Hordeum vulgare L. subsp. vulgare). Acta Physiol Plant 40:38. https://doi.org/10.1007/s11738-018-2604-0

Bouwmeester HJ, Matusova R, Zhongkui S, Beale MH (2003) Secondary metabolite signalling in host-parasitic plant interactions. Curr Opin Plant Biol 6:358-364. https://doi. org/10.1016/S1369-5266(03)00065-7

Bouwmeester HJ, Roux C, Lopez-Raez JA, Bécard G (2007) Rhizosphere communication of plants, parasitic plants and AM fungi. Trends Plant Sci 12:224-230. https://doi. org/10.1016/j.tplants.2007.03.009

Broeckling CD, Broz AK, Bergelson J, Manter DK, Vivanco JM (2008) Root exudates regulate soil fungal community composition and diversity. Appl Environ Microbiol 74:738-744. https://doi.org/10.1128/AEM.02188-07

Broz AK, Manter DK, Vivanco JM (2007) Soil fungal abundance and diversity: another victim of the invasive plant Centaurea maculosa. ISME J 1:763-765. https://doi.org/10.1038 /ismej.2007.81

Buee M, Rossignol M, Jauneau A, Ranjeva R, Bécard G (2000) The pre-symbiotic growth of arbuscular mycorrhizal fungi is induced by a branching factor partially purified from plant 
root exudates. Mol Plant-Microbe Interact 13:693-698. https://doi.org/10.1094/MPMI.2000.13.6.693

Buer CS, Muday GK, Djordjevic MA (2007) Flavonoids are differentially taken up and transported long distances in Arabidopsis. Plant Physiol 145:478-490. https://doi. org/10.1104/pp.107.101824

Caligiani A, Tonelli L, Palla G, Marseglia A, Rossi D, Bruni R (2013) Looking beyond sugars: phytochemical profiling and standardization of manna exudates from Sicilian Fraxinus excelsior L. Fitoterapia 90:65-72. https://doi.org/10.1016/j. fitote.2013.07.002

Chen YT, Wang Y, Yeh KC (2017) Role of root exudates in metal acquisition and tolerance. Curr Opin Plant Biol 39:66-72. https://doi.org/10.1016/j.pbi.2017.06.004

Cheng HH (1989) Assessment of the fate and transport of allelochemicals in the soil. In: Chou $\mathrm{CH}$, Waller GR (eds) Phytochemical ecology: allelochemicals, mytotoxins and insect pheromones and allomones. Institute of Botany, Academia Sinica Monogr. Ser. No 9, Taipei, ROC, 209

Cheng HH (1992) A conceptual framework for assessing allelochemicals in the soil environment. In: Rizvi SJK, Rizvi V (eds) Allelopathy: basic and applied aspects. Chapman \& Hall, London, pp 21-29. https://doi. org/10.1007/978-94-011-2376-1_3

Cheng HH (1995) Characterization of the mechanisms of allelopathy: modeling and experimental approaches. In: Inderjit, Dakshini KMM, Einhellig FA (eds) Allelopathy: organisms, processes and applications, ACS Sym. Ser. 582:132-141

Cheng HH, Koskinen WC (2010) Effects of "aging" on bioreactive chemical retention, transformation, and transport in soil. In: Xu J, Huang PM (eds) Molecular environmental soil science at the interfaces in the earth's critical zone. Springer, Berlin, Heidelberg, pp 184-186. https://doi. org/10.1007/978-3-642-05297-2_55

Chin-A-Woeng TFC, De Priester W, van der Bij AJ, Lugtenberg BJJ (1997) Description of the colonization of a gnotobiotic tomato rhizosphere by Pseudomonas fluorescens biocontrol strainWCS365, using scanning electron microscopy. Mol Plant Microbe In 10:79-86. https://doi.org/10.1094 /MPMI.1997.10.1.79

Clark FE (1949) Soil microorganisms and plant roots. Adv Agron 1:241-288. https://doi.org/10.1016/S0065-2113(08)60750-6

Compant S, Duffy B, Nowak J, Clément C, Barka EA (2005) Use of plant growth-promoting bacteria for biocontrol of plant diseases: principles, mechanisms of action, and future prospects. Appl Environ Microbiol 71(9):4951-4959. https://doi. org/10.1128/AEM.71.9.4951-4959.2005

Cook CE, Whichard LP, Wall ME, Egley GH, Coggon P, Luhan PA, McPhail AT (1972) Germination stimulants. 2. The structure of strigol - a potent seed germination stimulant for witchweed (Striga lutea Lour.). J Am Chem Soc 94:61986199. https://doi.org/10.1021/ja00772a048

Curie C, Panaviene Z, Loulergue C, Dellaporta SL, Briat JF, Walker EL (2001) Maize yellow stripe 1 encodes a membrane protein directly involved in Fe(III) uptake. Nature 409(6818): 346-349. https://doi.org/10.1038/35053080

Curlango-Rivera G, Huskey DA, Mostafa A, Kessler JO, Xiong Z, Hawes MC (2013) Intraspecies variation in cotton border cell production: Rhizosphere microbiome implications. Am J Bot 100:1706-1712. https://doi.org/10.3732/ajb.1200607
Czarnota MA, Paul RN, Weston LA, Duke SO (2003a) Anatomy of sorgoleone-secreting root hairs of Sorghum species. Int J Plant Sci 164:861-866. https://doi.org/10.1086/378661

Czarnota MA, Rimando AM, Weston LA (2003b) Evaluation of root exudates of seven sorghum accessions. J Chem Ecol 29: 2073-2083. https://doi.org/10.1023/A:1025634402071

Dakora FD, Phillips DA (2002) Root exudates as mediators of mineral acquisition in low-nutrient environments. Plant Soil 13:35-47. https://doi.org/10.1007/978-94-017-1570-6_23

Dalton BR, Blum U, Weed SB (1989) Differential sorption of exogenously applied ferulic $\rho$-coumaric, $\rho$-hydrohybenzoic and vanillic acids in soil. S Sci Soc Am J 53:757-762. https://doi.org/10.2136/sssaj1989.03615995005300030021x

Dao TH (1987) Sorption and mineralization of phenolic acids in soil. In: Walle GR (ed) Allelochemicals: role in agriculture and forestry. American Chemical Society, Washington, DC, pp 358-370

Darrah PR (1991) Models of the rhizosphere: II. A quasi threedimensional simulation of the microbial population dynamics around a growing root releasing soluble exudates. Plant Soil 138:147-158

Dayan FE (2006) Factors modulating the levels of the allelochemical sorgoleone in Sorghum bicolor. Planta 224: 339-346. https://doi.org/10.1007/s00425-005-0217-5

de Albuquerque MB, dos Santos RC, Lima LM, Filho PAM, Nogueira JMC, da Câmara CAG, Ramos AR (2011) Allelopathy, an alternative tool to improve cropping systems. A review. Agron Sustain Dev 31:379-395. https://doi. org/10.1051/agro/2010031

de Luque AP, Galindo JCG, Macías FA, Jorrín J (2000) Sunflower sesquiterpene lactone models induce Orobanche cumana seed germination. Phytochemistry 53:45-50. https://doi. org/10.1016/S0031-9422(99)00485-9

del Moral R, Muller CH (1970) The allelopathic effects of Eucalyptus camaldulensis. Am Midl Nat 83:254-282. https://doi.org/10.2307/2424020

De-la-Peña C, Lei Z, Watson BS, Sumner LW, Vivanco JM (2008) Root-microbe communication through protein secretion. J Biol Chem 283:25247-25255. https://doi.org/10.1074/jbc. M801967200

Dennis PG, Miller AJ, Clark IM, Taylor RG, Valsami-Jones E, Hirsch PR (2008) A novel method for sampling bacteria on plant root and soil surfaces at the microhabitat scale. J Microbiol Methods 75:12-18. https://doi.org/10.1016/j. mimet.2008.04.013

Dietz M, Machill S, Hoffmann HC, Schmidtke K (2013) Inhibitory effects of Plantago lanceolata L. on soil $\mathrm{N}$ mineralization. Plant Soil 368:445-458. https://doi.org/10.1007 /s11104-012-1524-9

Doornbos RF, van Loon LC, Bakker PAHM (2012) Impact of root exudates and plant defense signalling on bacterial communities in the rhizosphere. A review. Agron Sustain Dev 32:227243. https://doi.org/10.1007/s13593-011-0028-y

Dunfield KE, Germida JJ (2003) Seasonal changes in the rhizosphere microbial communities associated with field-grown genetically modified canola (Brassica napus). Appl Environ Microbiol 69:7310-7318. https://doi.org/10.1128 /AEM.69.12.7310-7318.2003

Eilers EJ, Veit D, Rillig MC, Hansson BS, Hilker M, Reinecke A (2016) Soil substrates affect responses of root feeding larvae to their hosts at multiple levels: orientation, locomotion and 
feeding. Basic Appl Ecol 17:115-124. https://doi. org/10.1016/j.baae.2015.09.006

El-Darier SM, Abdelaziz HA, Zein El-Dien MH (2014) Effect of soil type on the allelotoxic activity of Medicago sativa L. residues in Vicia faba L. agroecosystems. J Taibah Univ Sci 8:84-89. https://doi.org/10.1016/j.jtusci.2014.01.001

Fageria NK (2012) Role of soil organic matter in maintaining sustainability of cropping systems. Commun Soil Sci Plan 43: 2063-2113. https://doi.org/10.1080/00103624.2012.697234

Fang C, Smith P, Moncrieff JB, Smith JU (2005) Similar response of labile and resistant soil organic matter pools to changes in temperature. Nature 433:57-59. https://doi.org/10.1038 /nature 03138

Field B, Jordan F, Osbourn A (2006) First encounters - deployment of defence-related natural products by plants. New Phytol 172:193-207. https://doi.org/10.1111/j.14698137.2006.01863.x

Fuqua C, Parsek MR, Greenberg EP (2001) Regulation of gene expression by cell-to-cell communication: acyl-homoserine lactone quorum sensing. Annu Rev Genet 35:439-468. https://doi.org/10.1146/annurev.genet.35.102401.090913

Gamalero E, Lingua G, Giusy Caprì F, Fusconi A, Berta G, Lemanceau P (2004) Colonization pattern of primary tomato roots by Pseudomonas fluorescens A6ri characterized by dilution plating, flow cytometry, fluorescence, confocal and scanning electron microscopy. FEMS Microbiol Ecol 48:7987. https://doi.org/10.1016/j.femsec.2003.12.012

Gobran GR, Clegg S, Courchesne F (1998) Rhizospheric processes influencing the biogeochemistry of forest ecosystems. In: Van Breemen N (ed) Plant-induced soil changes: processes and feedbacks, Developments in Biogeochemistry, vol 4. Springer, Dordrecht, pp 107-120. https://doi.org/10.1007 /978-94-017-2691-7_6

Gomez-Roldan V, Fermas S, Brewer PB, Puech-Pagès V, Dun EA, Pillot JP et al (2008) Strigolactone inhibition of shoot branching. Nature 455:189-194. https://doi.org/10.1038 /nature07271

Goslee SC, Peters DPC, Beck KG (2001) Modeling invasive weeds in grasslands: the role of allelopathy in Acroptilon repens invasion. Ecol Model 139:31-45. https://doi. org/10.1016/S0304-3800(01)00231-9

Graham TL (1991) Flavonoid and isoflavonoid distribution in developing soybean seedling tissues and in seed and root exudates. Plant Physiol 95:594-603. https://doi.org/10.1104 /pp.95.2.594

Grossl PR (2008) Bioavailability of Allelochemicals in Soil. Utah State University, USA. Available on http://www.dtic. $\mathrm{mil} / \mathrm{dtic} / \mathrm{tr} /$ fulltext/u2/a495629.pdf. Accessed July 2018

Grotewold E (2001) Subcellular trafficking of phytochemicals. Rec Res Dev Plant Physiol 2:31-48

Gyamfi S, Pfeifer U, Stierschneider M, Sessitsch A (2002) Effects of transgenic glufosinate-tolerant oilseed rape (Brassica napus) and the associated herbicide application on eubacterial and Pseudomonas communities in the rhizosphere. FEMS Microbiol Ecol 41:181-190. https://doi.org/10.1111 jj.1574-6941.2002.tb00979.x

Härdtle W, von Oheimb G, Friedel A, Meyer H, Westphal C (2004) Relationship between $\mathrm{pH}$-values and nutrient availability in forest soils - the consequences for the use of ecograms in forest ecology. Flora 199:134-142
Hartmann A, Rothballer M, Schmid M (2008) Lorenz Hiltner, a pioneer in rhizosphere microbial ecology and soil bacteriology research. Plant Soil 312:7-4. https://doi.org/10.1007 /s11104-007-9514-z

Hawes MC, Curlango-Rivera G, Xiong Z, Kessler JO (2012) Roles of root border cells in plant defense and regulation of rhizosphere microbial populations by extracellular DNA "trapping". Plant Soil 355:1-16. https://doi.org/10.1007 /s11104-012-1218-3

Heisey RM (1996) Identification of an allelopathic compound from Ailanthus altissima (Simaroubaceae) and characterization of its herbicidal activity. Am J Bot 83:192-200. https://doi.org/10.1002/j.1537-2197.1996.tb12697.x

Hess DE, Ejeta G, Buttler LG (1992) Selecting sorghum genotypes expressing a quantitative biosynthetic trait that confers resistance to Striga. Phytochemistry 31:493-497. https://doi. org/10.1016/0031-9422(92)90023-J

Higgins CF (1992) ABC transporters: from microorganisms to man. Annu Rev Cell Biol 8:67-113

Hiltpold I, Jaffuel G, Turlings TCJ (2015) The dual effects of rootcap exudates on nematodes: from quiescence in plantparasitic nematodes to frenzy in entomopathogenic nematodes. J Exp Bot 66:603-611. https://doi.org/10.1093 /jxb/eru345

Hinsinger P (2001) Bioavailability of soil inorganic P in the rhizosphere as affected by root-induced chemical changes: a review. Plant Soil 237:173-195. https://doi.org/10.1023 /A:1013351617532

Hoffland E, Findenegg GR, Nelemans JA (1989) Solubilization of rock phosphate by rape. II. Local root exudation of organic acids as a response to P starvation. Plant Soil 113:161-165. https://doi.org/10.1007/BF02280176

Horrie H, Nemoto M, Nishimura N (1989) Dynamics of allelochemicals from broom (Cytisus scoparius) and their accumulation in soil. Weed Res Japan 34:47-56 (in Japanese with English summary)

Inderjit (2001) Soils: environmental effect on allelochemical activity. Agron J 93:79-84. https://doi.org/10.2134 /agronj2001.93179x

Inderjit C, Asakawa C (2001) Nature of interference potential of hairy vetch (Vicia villosa Roth) to radish (Raphanus sativus L.): does allelopathy play any role? Crop Prot 20:261-265. https://doi.org/10.1016/S0261-2194(00)00136-8

Inderjit, Bhowmik PC (2004) Sorption of benzoic acid onto soil colloids and its implications for allelopathy studies. Biol Fertil Soils 40:345-348. https://doi.org/10.1007/s00374004-0785-8

Inderjit, Dakshini KMM (1994) Allelopathic effect of Pluchea lanceolata (Asteraceae) on characteristics of four soils and tomato and mustard growth. Am J Bot 81:799-804. https://doi.org/10.1002/j.1537-2197.1994.tb15560.x

Inderjit, Weiner J (2001) Plant allelochemical interference or soil chemical ecology? Perspect Plant Ecol Evol Syst 4:3-12. https://doi.org/10.1078/1433-8319-00011

Inderjit, Kaur M, Foy CL (2001) On the significance of field studies in allelopathy. Weed Technol 15:792-797. https://doi.org/10.1614/0890-037X(2001)015[0792 :OTSOFS]2.0.CO;2

Iqbal Z, Hiradate S, Noda A, Isojima S, Fujii Y (2002) Allelopathy of buckwheat: Assessment of allelopathic potential of extract of aerial parts of buckwheat and identification of fagomine 
and other related alkaloids as allelochemicals. Weed Biol Manag 2:110-115. https://doi.org/10.1046/j.14456664.2002.00055.x

Itoh A, Ikuta Y, Baba Y, Tanahashi T, Nagakura N (1999) Ipecac alkaloids from Cephaelis acuminata. Phytochemistry 52: 1169-1176. https://doi.org/10.1016/S0031-9422(99)00361-1

Jabran K, Farooq M, Aziz T, Siddique KHM (2013) Allelopathy and crop nutrition. In: Cheema ZA, Farooq M, Wahid A (eds) Allelopathy: current trends and future applications. Springer, Verlag Berlin Heidelberg, Germany, pp 337-348. https://doi. org/10.1007/978-3-642-30595-5_14

Jansen van Rensburg HG, Claassens AS, Beukes DJ (2009) Relationships between soil buffer capacity and selected soil properties in a resource-poor farming area in the Mpumalanga Province of South Africa. S Afr J Plant Soil 26:237-243. https://doi.org/10.1080/02571862.2009.10639961

Jardine PM, Wilson GV, Luxmore RJ (1990) Unsaturated solute transport through a forest soil during rain storm events. Geoderma 46:103-118. https://doi.org/10.1016/0016-7061 (90)90010-7

Jennings JA, Nelson CJ (1998) Influence of soil texture on alfalfa autotoxicity. Agron J 90:54-58. https://doi.org/10.2134 /agronj1998.00021962009000010010x

Joe WH, Allen JR (1980) Effect of soil pH on plant growth and nodulation of cowpea. Commun Soil Sci Plan 11:1077-1085. https://doi.org/10.1080/00103628009367106

Johnson FF, Allan DL, Vance CP, Weiblen G (1996) Root carbon dioxide fixation by phosphorus-deficient Lupinus albus. Contribution to organic acid exudation by proteoid roots. Plant Physiol 112:19-30. https://doi.org/10.1104 /pp.112.1.19

Jones DL, Darrah PR (1994) Role of root derived organic acids in the mobilization of nutrients from the rhizosphere. Plant Soil 166:247-257. https://doi.org/10.1007/BF00008338

Jones DL, Darrah PR (1995) Influx and efflux of organic acids across the soil-root interface of Zea mays L. and its implications in rhizosphere C flow. Plant Soil 173:103-109. https://doi.org/10.1007/BF00155523

Jones DL, Hodge A, Kuzyakov Y (2004) Plant and mycorrhizal regulation of rhizodeposition. New Phytol 163:459-480. https://doi.org/10.1111/j.1469-8137.2004.01130.x

Jones DL, Nguyen C, Finlay RD (2009) Carbon flow in the rhizosphere: carbon trading at the soil-root interface. Plant Soil 321:5-33. https://doi.org/10.1007/s11104-009-9925-0

Kalinova J, Vrchotova N, Triska J (2007) Exudation of allelopathic substances in buckwheat (Fagopyrum esculentum Moench). J Agric Food Chem 55:6453-6459. https://doi. org/10.1021/jf070795u

Kato-Noguchi H, Hasegawa M, Ino T, Ota K, Kujime H (2010) Contribution of momilactone A and B to rice allelopathy. J Plant Physiol 167:787-791. https://doi.org/10.1016/j. jplph.2010.01.014

Kelsey RG, Locken LJ (1987) Phytotoxic properties of cnicin, a sesquiterpene lactone from Centaurea maculosa (spotted knapweed). J Chem Ecol 13:19-33. https://doi.org/10.1007 /BF01020348

Kennedy AC (1998) The rhizosphere and spermosphere. In: Sylvia DM, Fuhrmann JJ, Hartel PG, Zuberer DA (eds) Principles and applications of soil microbiology. Prentice Hall Inc., New Jersey, pp 389-407
Kidd PS, Llugany M, Poschenrieder C, Gunsé B, Barceló J (2001) The role of root exudates in aluminium resistance and siliconinduced amelioration of aluminium toxicity in three varieties of maize (Zea mays L.). J Exp Bot 52:1339-1352. https://doi. org/10.1093/jexbot/52.359.1339

Kloepper JW, Schippers B, Bakker PAHM (1992) Proposed elimination of the term endorhizosphere. Phytopathology 82 : $726-727$

Kobayashi K (2004) Factors affecting phytotoxic activity of allelochemicals in soil. Weed Biol Manag 4:1-7. https://doi. org/10.1111/j.1445-6664.2003.00112.x

Kochian LV, Hoekenga OA, Piñeros MA (2004) How do crop plants tolerate acid soils? Mechanisms of aluminum tolerance and phosphorus efficiency. Annu Rev Plant Biol 55:459-493. https://doi.org/10.1146/annurev.arplant.55.031903.141655

Kruse M, Strandberg M, Strandberg B (2000) Ecological effects of allelopathic plants - a Review. National Environmental Research Institute, Silkeborg, Denmark. 66 pp. - NERI Technical Report No. 315

Kulmatiski A, Beard KH (2006) Activated carbon as a restoration tool: potential for control of invasive plants in abandoned agricultural fields. Restor Ecol 14:251-257. https://doi. org/10.1111/j.1526-100X.2006.00127.x

Lavelle P, Spain AV (2001) Soil ecology. Kluwer Academic Pub, Dordrecht

Li Q, Yuan L, Huang J (2014) Allelopathic effects of artemisinin on ectomycorrhizal fungal isolates in vitro. Pedobiologia 57: 271-276. https://doi.org/10.1016/j.pedobi.2014.07.002

Liu Q, Xu R, Yan Z, Jin H, Cui H, Lu L, Zhang D, Qin B (2013) Phytotoxic allelochemicals from roots and root exudates of Trifolium pratense. J Agric Food Chem 61:6321-6327. https://doi.org/10.1021/jf401241e

Lucas Garcia JA, Barbas C, Probanza A, Barrientos ML, Gutierrez Mañero FJ (2001) Low molecular weight organic acids and fatty acids in root exudates of two Lupinus cultivars at flowering and fruiting stages. Phytochem Anal 12:305-311. https://doi.org/10.1002/pca.596

Luo Q, Wang S, Sun L, Wang H (2017) Metabolic profiling of root exudates from two ecotypes of Sedum alfredii treated with $\mathrm{Pb}$ based on GC-MS. Sci Rep 7:39878. https://doi.org/10.1038 /srep39878

Lynch JM (1987) The rhizosphere. Wiley Interscience, Chichester, UK

Ma Y (2005) Allelopathic studies of common wheat (Triticum aestivum L.). Weed Biol Manag 5:93-104. https://doi. org/10.1111/j.1445-6664.2005.00164.x

Ma JF, Ryan PR, Delhaize E (2001) Aluminium tolerance in plants and the complexing role of organic acids. Trends Plant Sci 6: 273-278. https://doi.org/10.1016/S1360-1385(01)01961-6

Makarova LE, Dudareva LV, Petrova IG, Vasil'eva GG (2016) Secretion of phenolic compounds into root exudates of pea seedlings upon inoculation with Rhizobium leguminosarum bv. viceae or Pseudomonas siringae pv. pisi. Appl Biochem Microbiol 52:205-209. https://doi.org/10.1134 /S0003683816020095

Marschner H (1995) Mineral Nutrition of Higher Plants. Academic Press, London, UK

Mazzaglia A, Licciardello F, Scavo A, Muratore G, Mauromicale G, Restuccia C (2018) Effect of Cynara cardunculus extract on the shelf life of aubergine burgers. Ital J Food Sci 30:1923 
McCauley A, Jones C, Jacobsen J (2009) Soil pH and organic matter. Nutrient management modules, vol 8, pp 4449-8, pp 1-12. MontanaState University Extension Service, Bozeman, Montana

McNear DH Jr (2013) The rhizosphere - roots, soil and everything in between. Nature Education Knowledge 4(3):1

Meda AR, Scheuermann EB, Prechsl UE, Erenoglu B, Schaaf G, Hayen H (2007) Iron acquisition by phytosiderophores contributes to cadmium tolerance. Plant Physiol 143:1761-1773. https://doi.org/10.1104/pp.106.094474

Morello JE, Pierson EA, Pierson LS (2004) Negative crosscommunication among wheat rhizosphere bacteria: effect on antibiotic production by the biological control bacterium Pseudomonas aureofaciens. Appl Environ Microbiol 70: 3103-3109. https://doi.org/10.1128/AEM.70.5.31033109.2004

Nagahashi G, Douds DD (1999) Rapid and sensitive bioassay to study signals between root exudates and arbuscular mycorrhizal fungi. Biotechnol Tech 13:893-897. https://doi. org/10.1023/A:1008938527757

Neumann G, Romheld V (2001) The release of root exudates as affected by the plant's physiological status. In: Pinton R, Varanini Z, Nannipieri P (eds) The rhizosphere, biochemistry and organic substances at the soil-plant interface. Marcel Dekker, New York, NY, USA, pp 41-93

Niemeyer HM, Bravo HR, Peña GF (1982) Corcuera LJ (1982) Decomposition of 2,4-dihydroxy-7-methoxy-2H-1,4-benzoxazin-3-(4H)-one, a hydroxamic acid from Gramineae. In: Kehl H (ed) Chemistry and Biology of Hydroxamic Acids. 1st International Symposium, Dayton, Ohio, May 1981. Karger, Basel, pp 22-28. https://doi.org/10.1159 /000430626

Norouzi Y, Mohammadi GR, Nosratti I (2015) Soil factors affecting the allelopathic activities of some plant species. AmerEurasian J Agri \& Environ Sciences 15(11):2252-2257. https://doi.org/10.5829/idosi.aejaes.2015.15.11.12594

Noy-Meir I (1973) Desert ecosystems: environment and producers. Annu Rev Ecol Syst 4:25-52. https://doi. org/10.1146/annurev.es.04.110173.000325

Nozoye T, Aung SA, Masuda H, Nakanishi H, Nishizawa NK (2017) Bioenergy grass [Erianthus ravennae (L.) Beauv.] secretes two members of mugineic acid family phytosidrophores which involved in their tolerance to Fe deficiency. Soil Sci Plant Nutr 63:543-552. https://doi. org/10.1080/00380768.2017.1394168

Omote H, Hiasa M, Matsumoto T, Otsuka M, Moriyama Y (2006) The MATE proteins as fundamental transporters of metabolic and xenobiotic organic cations. Trends Pharmacol Sci 27: 587-593. https://doi.org/10.1016/j.tips.2006.09.001

Osmont KS, Sibout R, Hardtke CS (2007) Hidden branches: developments in root system architecture. Annu Rev Plant Biol 58:93-113. https://doi.org/10.1146/annurev. arplant.58.032806.104006

Pagliai M, Vignozzi N (2002) The soil pore system as an indicator of soil quality. Adv GeoEcology 35:69-80

Pearson R, Parkinson D (1961) The sites of excretion of ninhydrin-positive substances by broad bean seedlings. Plant Soil 13:391-396. https://doi.org/10.1007/BF01394650

Pérez FJ, Ormeño-Nuñez J (1991) Root exudates of wild oats: Allelopathic effect on spring wheat. Phytochemistry 30: 2199-2202. https://doi.org/10.1016/0031-9422(91)83614-Q
Perret X, Staehelin C, Broughton WJ (2000) Molecular basis of symbiotic promiscuity. Microbiol Mol Biol Rev 64:180-201. https://doi.org/10.1128/MMBR.64.1.180-201.2000

Peters NK, Long SR (1988) Alfalfa root exudates and compounds which promote or inhibit induction of Rhizobium meliloti nodulation genes. Plant Physiol 88:396-400. https://doi. org/10.1104/pp.88.2.396

Peters NK, Frost JW, Long SR (1986) A plant flavone, luteolin, induces expression of Rhizobium meliloti nodulation genes. Science 233:977-980. https://doi.org/10.1126 /science. 3738520

Phillips DA, Tsai SM (1992) Flavonoids as plant signals to rhizosphere microbes. Mycorrhiza 1:55-58. https://doi. org/10.1007/BF00206136

Pina ES, Silva DB, Teixeira SP, Coppede JS, Furlan M, Franca SC, Lopes NP, Pereira AMS, Lopes AA (2016) Mevalonatederived quinonemethide triterpenoid from in vitro roots of Peritassa laevigata and their localization in root tissue by MALDI imaging. Sci Rep 6:22627. https://doi.org/10.1038 /srep22627

Pineros MA, Magalhaes JV, Alves VMC, Kochian LV (2002) The physiology and biophysics of an aluminium tolerance mechanism based on root citrate exudation in maize. Plant Physiol 129:1194-1206. https://doi.org/10.1104/pp.002295

Podile AR, Kishore GK (2006) Plant growth-promoting rhizobacteria. In: S.S. Gnanamanickam (ed.) - PlantAssociated Bacteria. Springer, Netherlands, pp. 195-230

Qin B, Perry LG, Browckling CD, Du J, Stermitz F, Paschke MW, Vivanco JM (2006) Phytotoxic allelochemicals from roots and root exudates of leafy spurge (Euphorbia esula L.). Plant Signal Behav 1:323-327. https://doi.org/10.4161 /psb.1.6.3563

Rasmann S, Köllner TG, Degenhardt J, Hiltpold I, Toepfer S, Kuhlmann U, Gershenzon J, Turlings TCJ (2005) Recruitment of entomopathogenic nematodes by insectdamaged maize roots. Nature 434:732-737. https://doi. org/10.1038/nature03451

Raupp FM, Spring O (2013) New sesquiterpene lactones from sunflower root exudate as germination stimulants for Orobanche Cumana. J Agric Food Chem 61:10481-10487. https://doi.org/10.1021/jf402392e

Rhoades JD (1982) Cation exchange capacity. In: Page AL et al. (eds) Methods of soil analysis. Part 2, $2^{\text {nd }}$ Edition. ASA and SSSA, Madison, WI. Agron Monogr 9:149-158

Rial C, Gómez E, Varela RM, Molinillo JMG, Macías FA (2018) Ecological relevance of the major allelochemicals in Lycopersicon esculentum roots and exudates. J Agric Food Chem 66:4638-4644. https://doi.org/10.1021/acs.jafc.8 b01501

Rice EL (1984) Allelopathy, 2nd edn. Academic Press, New York

Rietveld WJ, Schlesinger RC, Kessler KJ (1983) Allelopathic effects of black walnut on European black alder coplanted as a nurse species. J Chem Ecol 9:1119-1133. https://doi. org/10.1007/BF00982216

Ringrose-Voase AJ, Bullock P (1984) The automatic recognition and measurement of soil pore types by image analysis and computer programs. J Soil Sci 35:673-684. https://doi. org/10.1111/j.1365-2389.1984.tb00624.x

Robatzek S (2007) Vesicle trafficking in plant immune responses. Cell Microbiol 9:1-8. https://doi.org/10.1111/j.14625822.2006.00829.x 
Robert CAM, Erb M, Duployer M, Zwahlen C, Doyen GR, Turlings TCJ (2012) Herbivore-induced plant volatiles mediate host selection by a root herbivore. New Phytol 194:10611069. https://doi.org/10.1111/j.1469-8137.2012.04127.x

Romeo JT (2000) Raising the baem: moving beyond phytotoxicity. J Chem Ecol 26:2011-2014. https://doi.org/10.1023 /A:1005599828335

Römheld V, Marschner H (1990) Genotypical differences among graminaceous species in release of phytosiderophores and uptake of iron phytosiderophores. In: El Bassam N, Dambroth M, Loughman BC (eds) Genetic aspects of plant mineral nutrition. Dev Plant Soil Sci 42:77-83, Springer, Dordrecht. https://doi.org/10.1007/978-94-009-2053-8_12

Rousk J, Brookes PC, Bååth E (2009) Contrasting soil pH effects on fungal and bacterial growth suggest functional redundancy in carbon mineralization. Appl Environ Microbiol 75: 1589-1596. https://doi.org/10.1128/AEM.02775-08

Rovira AD (1969) Plant root exudates. Bot Rev 35:35-57. https://doi.org/10.1007/BF02859887

Rovira AD, Davey CB (1974) Biology of rhizosphere. In: Carson EW (ed) The plant root and its environment. University Press of Virginia, Charlottesville, pp 153-204

Ryan PR, Delhaize E, Randall PJ (1995) Characterisation of Alstimulated efflux of malate from the apices of Al-tolerant wheat roots. Planta 196:103-110. https://doi.org/10.1007 /BF00193223

Sasaki T, Yamamoto Y, Ezaki B, Katsuhara M, Ju AS, Ryan PR, Delhaize E, Matsumoto H (2004) A wheat gene encoding an aluminum-activated malate transporter. Plant J 37:645-653. https://doi.org/10.1111/j.1365-313X.2003.01991.x

Scavo A, Restuccia A, Mauromicale G (2018a) Allelopathy: principles and basic aspects for agroecosystem control. In: Gaba S, Smith B, Lichtfouse E (eds) Sustainable Agriculture Reviews 28. Sustainable Agriculture Reviews, Springer, Cham, vol 28, pp 47-101

Scavo A, Restuccia A, Pandino G, Onofri A, Mauromicale G (2018b) Allelopathic effects of Cynara cardunculus L. leaf aqueous extracts on seed germination of some Mediterranean weed species. Ital J Agron 13:119-125. https://doi. org/10.4081/ija.2018.1021

Scavo A, Pandino G, Restuccia C, Parafiti L, Cirvilleri G, Mauromicale G (2019a) Antimicrobial activity of cultivated cardoon (Cynara cardunculus L. var. altilis DC.) leaf extracts against bacterial species of agricultural and food interest. Ind Crop Prod 129:206-211. https://doi.org/10.1016/j. indcrop.2018.12.005

Scavo A, Restuccia A, Abbate C, Mauromicale G (2019b) Seeming field allelopathic activity of Cynara cardunculus L. reduces the soil weed seed bank. Agron Sustain Develop (In Press.). https://doi.org/10.1007/s13593-019-0580-4

Scavo A, Rial C, Molinillo JMG, Varela RM, Mauromicale G, Macías FA (2019c) The extraction procedure improves the allelopathic activity of cardoon (Cynara cardunculus var. altilis) leaf allelochemicals. Ind Crop Prod 128:479-487. https://doi.org/10.1016/j.indcrop.2018.11.053

Scavo A, Pandino G, Restuccia A, Lombardo S, Pesce RG, Mauromicale G (2019d) Allelopathic potential of leaf aqueous extracts from Cynara cardunculus L. on the seedling growth of two cosmopolitan weed species. Ital J Agron 14: 78-83. https://doi.org/10.4081/ija.2019.1373

Scavo A, Rial C, Varela RM, Molinillo JMG, Mauromicale G, Macías FA (2019e) Influence of genotype and harvest time on the Cynara cardunculus L. sesquiterpene lactone profile. J Agric Food Chem 67, 23:6487-6496. https://doi.org/10.1021 /acs.jafc.9b02313

Schmidt S, Ley RE (1999) Microbial competition and soil structure limit the expression of allelochemicals in nature. In: Dakshihi KMM, Foy CL (eds) Inderjit. Principles and Practices in Plant Ecology. CRC Press, Boca Raton, FL, pp 339-351

Senoura T, Sakashita E, Kobayashi T, Takahashi M, Aung MS, Masuda H, Nakanishi H, Nishizawa NK (2017) The ironchelate transporter OsYSL9 plays a role in iron distribution in developing rice grains. Plant Mol Biol 95:375-387. https://doi.org/10.1007/s11103-017-0656-y

Shaukat SS, Munir N, Siddiqui IA (2003) Allelopathic responses of Conyza canadensis (L.) Cronquist: a cosmopolitan weed. Asian J Plant Sci 2:1034-1039

Smalla K, Wieland G, Buchner A, Zock A, Parzy J, Kaiser S, Roskot N, Heuer H, Berg G (2001) Bulk and rhizosphere soil bacterial communities studied by denaturing gradient gel electrophoresis: plant-dependent enrichment and seasonal shifts revealed. Appl Environ Microbiol 67:4742-4751. https://doi.org/10.1128/AEM.67.10.4742-4751.2001

Somers E, Vanderleyden J, Srinivasan M (2004) Rhizosphere bacterial signalling: a love parade beneath our feet. Crit Rev Microbiol 30:205-235. https://doi.org/10.1080 /10408410490468786

Steele HL, Werner D, Cooper JE (1999) Flavonoids in seed and root exudates of Lotus pedunculatus and their biotransformation by Mesorhizobium loti. Physiol Plant 107:251-258. https://doi.org/10.1034/j.1399-3054.1999.100301.x

Steenhoudt O, Vanderleyden J (2000) Azospirillum, a free-living nitrogen-fixing bacterium closely associated with grasses: genetic, biochemical and ecological aspects. FEMS Microbiol Rev 24:487-506. https://doi.org/10.1111/j.15746976.2000.tb00552.x

Subbarao GV, Kishii M, Nakahara K, Ishikawa T, Ban T, Tsujimoto H, George TS, Berry WL, Hash CT, Ito O (2009) Biological nitrification inhibition (BNI)-is there potential for genetic interventions in the Triticeae? Breed Sci 59:529-545. https://doi.org/10.1270/jsbbs.59.529

Sugiura Y, Nomoto K (1984) Phytosiderophores structures and properties of mugineic acids and their metal complexes. In: Chimiak A, Hider RC, Liu A, Neilands JB, Nomoto K, Sugiura Y (eds) Siderophores from Microorganisms and Plants. Structure and Bonding, 58:107-135, Springer, Berlin, Heidelberg. https://doi.org/10.1007/BFb0111313

Sugiyama A, Shitan N, Yazaki K (2007) Involvement of a soybean ATP-binding cassette-type transporter in the secretion of genistein, a signal flavanoid in legume-Rhizobium symbiosis. Plant Physiol 144:2000-2008. https://doi.org/10.1104 /pp.107.096727

Suksungworn R, Sanevas N, Wongkantrakorn N, Fangern N, Vajrodaya S, Duangsrisai S (2016) Phytotoxic effect of Haldina cordifolia on germination, seedling growth and root 
cell viability of weeds and crop plants. NJAS-Wageningen J Life Sci 78:175-181. https://doi.org/10.1016/j. njas.2016.05.008

Suzuki M, Nozoye T, Nagasaka S, Nakanishi H, Nishizawa NK, Mori S (2016) The detection of endogenous 2'deoxymugineic acid in olives (Olea europaea L.) indicates the biosynthesis of mugineic acid family phytosiderophores in non-graminaceous plants. Soil Sci Plant Nutr 62:481-488. https://doi.org/10.1080/00380768.2016.1230724

Taiz L, Zeiger E (2002) Plant physiology. Ed. 3. Sinauer Associates, Inc., Sunderland

Técher D, Laval-Gilly P, Henry S, Bennasroune A, Formanek P, Martinez-Chois C, D'Innocenzo M, Muanda F, Dicko A, Rejšek K, Falla J (2011) Contribution of Miscanthus $x$ giganteus root exudates to the biostimulation of PAH degradation: An in vitro study. Sci Total Environ 409:4489-4495. https://doi.org/10.1016/j.scitotenv.2011.06.049

Teske A, Alm E, Regan JM, Toze S, Rittmann BE, Stahl DA (1994) Evolutionary relationships among ammonia- and nitrite-oxidizing bacteria. J Bacteriol 176:6623-6630. https://doi.org/10.1128/jb.176.21.6623-6630.1994

Tharayil N, Triebwasser DJ (2010) Elucidation of a diurnal pattern of catechin exudation by Centaurea stoebe. J Chem Ecol 36: 200-204. https://doi.org/10.1007/s10886-010-9749-7

Tharayil N, Bhowmik P, Alpert P, Walker E, Amarasiriwardena D, Xing B (2009) Dual purpose secondary compounds: phytotoxin of Centaurea diffusa also facilitates nutrient uptake. New Phytol 181:424-434. https://doi.org/10.1111 /j.1469-8137.2008.02647.x

Thompson LK, Hale MG (1983) Effects of kinetin in the rooting medium on root exudation of free fatty acids and sterols from roots of Arachis hypogaea L. "Argentine" under axenic conditions. Soil Biol Biochem 15:125-126

Tsai HH, Schmidt W (2017) Mobilization of iron by plant-borne coumarins. Trends Plant Sci 22:538-548. https://doi. org/10.1016/j.tplants.2017.03.008

Ueno D, Rombola AD, Iwashita T, Nomoto K, Ma JF (2007) Identification of two novel phytosiderophores secreted by perennial grasses. New Phytol 174:304-310. https://doi. org/10.1111/j.1469-8137.2007.02056.x

Uren NC (2000) Types, amounts, and possibile functions of compounds released into the rhizosphere by soil-grown plants. In: Willig S, Varanini Z, Nannipieri P (eds) The rhizosphere: biochemistry and organic substances at the soil-plant interface. Marcel Dekker, Inc, New York

Valentinuzzi F, Cesco S, Tomasi N, Mimmo T (2016) Effect of aluminium exposure on the release of organic acids and genistein from the roots of Lupinus albus L. plants. Rhizosphere 1:29-32. https://doi.org/10.1016/j. rhisph.2016.07.002

van Dam NM, Bouwmeester HJ (2016) Metabolomics in the rhizosphere: tapping into belowground chemical communication. Trends Plant Sci 21:256-265. https://doi.org/10.1016 j.tplants.2016.01.008

Van Loon LC (2007) Plant responses to plant growth-promoting rhizobacteria. In: Bakker PAHM, Raaijmakers JM, Bloemberg G, Höfte M, Lemanceau P, Cooke BM (eds) New perspectives and approaches in plant growth- promoting rhizobacteria research. Springer, Dordrecht, pp 243-254. https://doi.org/10.1007/978-1-4020-6776-1_2

Vaughan MM, Wang Q, Webster FX, Kiemle D, Hong YJ, Tantillo DJ et al (2013) Formation of the unusual semivolatile diterpene rhizathalene by the Arabidopsis class I terpene synthase TPS08 in the root stele is involved in defense against belowground herbivory. Plant Cell 25:1108-1125. https://doi. org/10.1105/tpc.112.100057

Vogel CS, Dawson JO (1985) Effect of juglone on growth in vitro of Frakia isolates and nodulation of Alnus glutinosa in soil. Plant Soil 87:79-89. https://doi.org/10.1007/BF02277650

Wagner GH, Wolf DC (1998) Carbon transformation and soil organic matter formation. In: Sylvia DM, Fuhrmann JJ, Hartel PG, Zuberer DA (eds) Principles and applications of soil microbiology. SSSA Special Publication 17, Soil Science Society of America, Madison, pp 251-281

Walker TS, Bais HP, Grotewold E, Vivanco JM (2003) Root exudation and rhizosphere biology. Plant Physiol 132:44 51. https://doi.org/10.1104/pp.102.019661

Wang Z, Straub D, Yang H, Kania A, Shen J, Ludewig U, Neumann G (2014) The regulatory network of cluster-root function and development in phosphate-deficient white lupin (Lupinus albus) identified by transcriptome sequencing. Physiol Plant 151:323-338. https://doi.org/10.1111 /ppl.12187

Watt M, Hugenholtz P, White R, Vinall K (2006) Numbers and locations of native bacteria on field-grown wheat roots quantified by fluorescence in situ hybridization (FISH). Environ Microbiol 8:871-884. https://doi.org/10.1111/j.14622920.2005.00973.x

Weidenhamer JD (1996) Distinguishing resource competition and chemical interference: Overcoming the methodological impasse. Agron J 8:866-875. https://doi.org/10.2134 /agronj1996.00021962003600060005x

Weil RR, Brady NC (2017) The nature and property of soils. Pearson Education, $15^{\text {th }}$ Edition. ISBN: 978-0133254488

Weston LA, Ryan PR, Watt M (2012) Mechanisms for cellular transport and release of allelochemicals from plant roots into the rhizosphere. J Exp Bot 63:3445-3454. https://doi. org/10.1093/jxb/ers054

Wu H, Haig T, Pratley J, Lemerle D, An M (2001) Allelochemicals in wheat (Triticum aestivum L.): cultivar difference in the exudation of phenolic acids. J Agric Food Chem 49:37423745. https://doi.org/10.1021/jf010111x

Yan N (2013) Structural advances for the major facilitator superfamily (MFS) transporters. Trends Biochem Sci 38:151-159. https://doi.org/10.1016/j.tibs.2013.01.003

York LM, Carminati A, Mooney SJ, Ritz K, Bennett MJ (2016) The holistic rhizosphere: integrating zones, processes, and semantics in the soil influenced by roots. J Exp Bot 67:36293643. https://doi.org/10.1093/jxb/erw108

Yu JQ, Matsui Y (1997) Effects of root exudates of cucumber (Cucumis sativus) and allelochemicals on ion uptake by cucumber seedlings. J Chem Ecol 23:817-827. https://doi. org/10.1023/B:JOEC.0000006413.98507.55

Yu JQ, Ye SF, Zhang MF, Hu WH (2003) Effects of root exudates and aqueous root extracts of cucumber (Cucumis sativus) and allelochemicals, on photosynthesis and antioxidant enzymes 
in cucumber. Biochem Syst Ecol 31:129-139. https://doi. org/10.1016/S0305-1978(02)00150-3

Zhao J, Dixon RA (2009) MATE transporters facilitate vacuolar uptake of epicatechin 3'-O-glucoside for proanthocyanidin biosynthesis in Medicago truncatula and Arabidopsis. Plant Cell 21:2323-2340. https://doi.org/10.1105/tpc.109.067819

Zhao B, Agblevor FA, Ritesh KC, Jelesko JG (2013) Enhanced production of the alkaloid nicotine in hairy root cultures of
Nicotiana tabacum L. Plant Cell Tissue Organ Cult 113:121129. https://doi.org/10.1007/s11240-012-0256-0

Publisher's note Springer Nature remains neutral with regard to jurisdictional claims in published maps and institutional affiliations. 